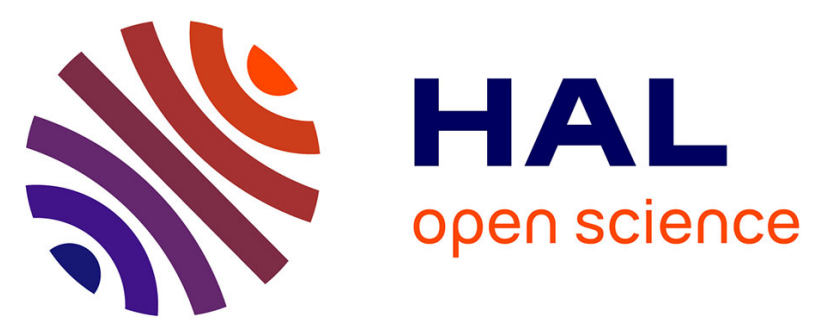

\title{
Fingerprinting sediment sources in the outlet reservoir of a hilly cultivated catchment in Tunisia
}

\author{
Abir Ben Slimane, Damien Raclot, O. Evrard, Mustapha Sanaa, Irène \\ Lefevre, Mehdi Ahmadi, Mouna Tounsi, Cornelia Rumpel, Abdallah Ben \\ Mammou, Yves Le Bissonnais
}

\section{To cite this version:}

Abir Ben Slimane, Damien Raclot, O. Evrard, Mustapha Sanaa, Irène Lefevre, et al.. Fingerprinting sediment sources in the outlet reservoir of a hilly cultivated catchment in Tunisia. Journal of Soils and Sediments, 2013, 13 (4), pp.801-815. 10.1007/s11368-012-0642-6 . cea-02615650

\section{HAL Id: cea-02615650 https://hal-cea.archives-ouvertes.fr/cea-02615650}

Submitted on 23 May 2020

HAL is a multi-disciplinary open access archive for the deposit and dissemination of scientific research documents, whether they are published or not. The documents may come from teaching and research institutions in France or abroad, or from public or private research centers.
L'archive ouverte pluridisciplinaire HAL, est destinée au dépôt et à la diffusion de documents scientifiques de niveau recherche, publiés ou non, émanant des établissements d'enseignement et de recherche français ou étrangers, des laboratoires publics ou privés. 


\section{SEDIMENTS, SEC 3 • HILLSLOPE AND RIVER BASIN SEDIMENT DYNAMICS •} RESEARCH ARTICLE

3

Fingerprinting sediment sources in the outlet reservoir of a hilly cultivated catchment of

\section{Tunisia}

\section{Abir Ben Slimane • Damien Raclot • Olivier Evrard • Mustapha Sanaa • Irène Lefèvre • Mehdi Ahmadi • Mouna Tounsi • Cornelia Rumpel • Abdallah Ben Mammou • Yves le Bissonnais}

\section{A. Ben Slimane $・$ M. Sanaa} Institut National Agronomique de Tunisie, 43, Avenue Charles Nicolle 1082, TunisMahrajène, Tunisia
A. Ben Slimane $・$ D. Raclot $(\square)$ IRD-UMR LISAH(INRA-IRD-Supagro), 2 Place Viala, 34060 Montpellier, France e-mail: damien.raclot@ird.fr

O. Evrard • I. Lefèvre • M. Ahmadi Laboratoire des Sciences du Climat et de l'Environnement (LSCE/IPSL) - Unité Mixte de Recherche 8212 (CEA, CNRS, UVSQ), 91198 Gif-sur-Yvette Cedex, France

M. Tounsi • A. Ben Mammou

Laboratoire des Ressources Minérales et Environnement, Département de Géologie, Faculté des Sciences de Tunis, Université Tunis El Manar, 2092 Tunis, El Manar, Tunisia

C. Rumpel Bioemco (UPMC - CNRS - INRA - ENS - UPEC- IRD - AgroParisTech), Centre INRA Versailles-Grignon Bâtiment EGER, 78850 Thiverval-Grignon, France

Y. le Bissonnais

INRA-UMR LISAH (INRA-IRD-Supagro), 2 Place Viala, 34060 Montpellier, France

\section{( $\bowtie)$ Corresponding author:}

Damien Raclot

Phone: +33 (0)4 99612139

Fax: +33 (0)467632614

e-mail: damien.raclot@ird.fr 


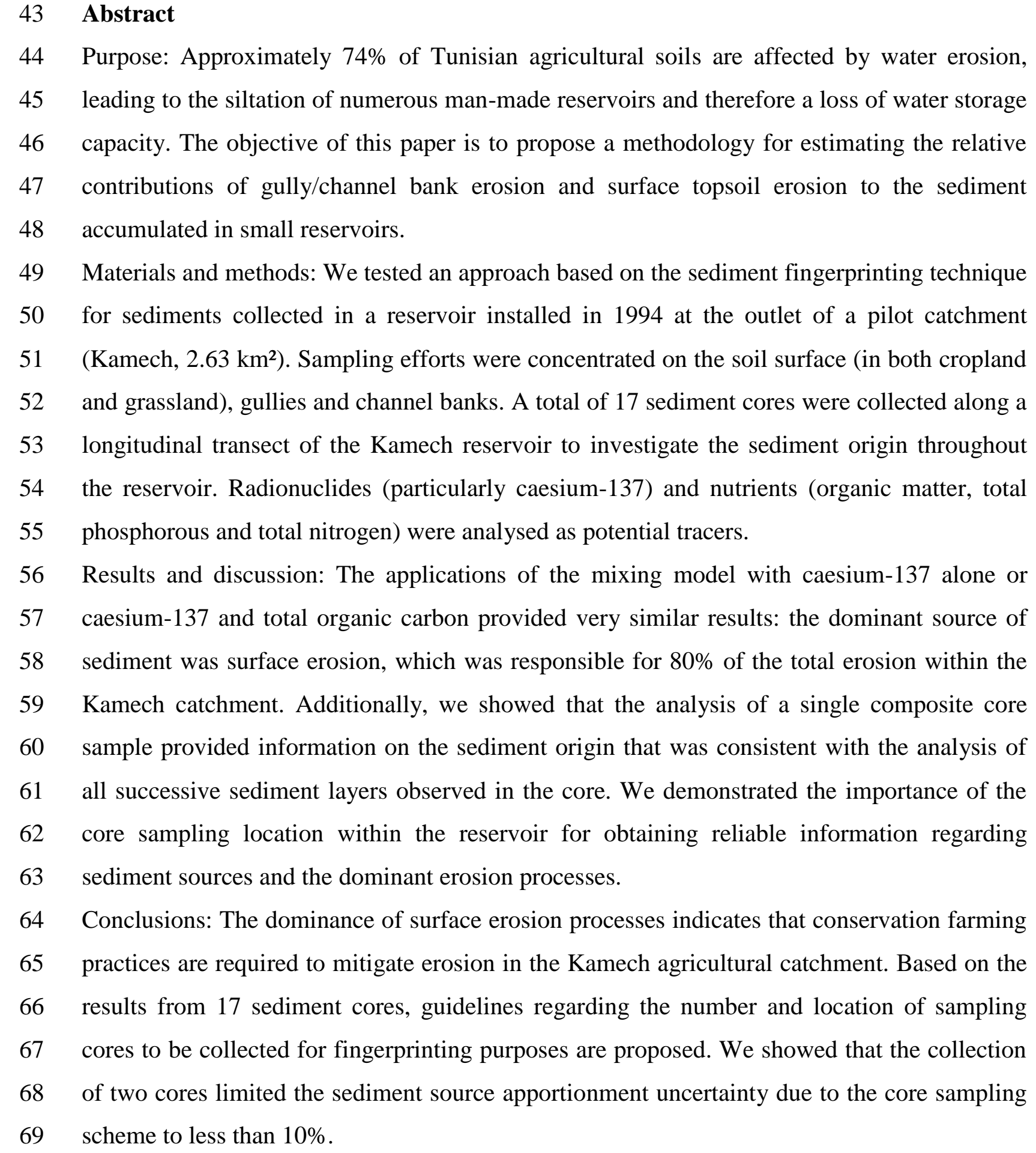

Purpose: Approximately $74 \%$ of Tunisian agricultural soils are affected by water erosion, leading to the siltation of numerous man-made reservoirs and therefore a loss of water storage capacity. The objective of this paper is to propose a methodology for estimating the relative contributions of gully/channel bank erosion and surface topsoil erosion to the sediment accumulated in small reservoirs.

Materials and methods: We tested an approach based on the sediment fingerprinting technique for sediments collected in a reservoir installed in 1994 at the outlet of a pilot catchment (Kamech, $2.63 \mathrm{~km}^{2}$ ). Sampling efforts were concentrated on the soil surface (in both cropland and grassland), gullies and channel banks. A total of 17 sediment cores were collected along a longitudinal transect of the Kamech reservoir to investigate the sediment origin throughout the reservoir. Radionuclides (particularly caesium-137) and nutrients (organic matter, total phosphorous and total nitrogen) were analysed as potential tracers.

Results and discussion: The applications of the mixing model with caesium-137 alone or caesium-137 and total organic carbon provided very similar results: the dominant source of sediment was surface erosion, which was responsible for $80 \%$ of the total erosion within the Kamech catchment. Additionally, we showed that the analysis of a single composite core sample provided information on the sediment origin that was consistent with the analysis of all successive sediment layers observed in the core. We demonstrated the importance of the core sampling location within the reservoir for obtaining reliable information regarding sediment sources and the dominant erosion processes.

Conclusions: The dominance of surface erosion processes indicates that conservation farming practices are required to mitigate erosion in the Kamech agricultural catchment. Based on the results from 17 sediment cores, guidelines regarding the number and location of sampling cores to be collected for fingerprinting purposes are proposed. We showed that the collection of two cores limited the sediment source apportionment uncertainty due to the core sampling scheme to less than $10 \%$.

Keywords Catchment $\bullet$ Fingerprinting technique $\bullet$ Reservoir $\bullet$ Gully erosion $\bullet$ Rill and interrill erosion $\bullet$ Source sediment $\bullet$ Core sampling strategy. 


\section{Introduction}

Soil erosion is a major environmental problem that threatens agricultural sustainability and productivity (EEA 2000; Pimentel et al. 1995). This process disturbs downstream ecosystems by transferring contaminants and nutrients associated with fine-grained sediment from croplands to rivers (Owens et al. 2005). Mediterranean countries are commonly reported to be severely affected by soil erosion due to their climatic instability, poor soil properties, and the occasional use of inappropriate farming practices (e.g., Cantón et al. 2011; Lesschen et al. 2008; Mougou et al. 2006). Moreover, climate change projections outline an increase in rainfall intensities, leading to an increased vulnerability of Mediterranean ecosystems. In North African countries, and Tunisia in particular, numerous reservoirs have been constructed in hilly environments in recent decades to provide water for agriculture through surface water mobilisation (Albergel et al. 2005). However, the siltation of these artificial reservoirs due to soil erosion is a major problem, and several existing reservoirs in Tunisia have been completely filled with sediment in less than 10 years (Hentati et al. 2010). Numerous studies have been conducted to quantify erosion rates in Tunisian agricultural regions. Several investigations have used models, such as the Universal Soil Loss Equation (Albergel et al. 1998; Ben Cheikha and Gueddari 2008) or the Water Erosion Prediction Project erosion model (Raclot et al. 2006), to estimate or predict the volume of accumulated sediment in catchment reservoirs over several decades. Other studies have focused on the quantification of the gully erosion process using aerial and satellite imagery (Bouchnak et al. 2009; Desprats et al. 2012) or topographic surveys of individual gullies (Collinet and Zante 2005). The majority of these studies implicated gully erosion as the main source of sediment in the Mediterranean region (e.g., de Vente et al. 2006, 2008; Poesen et al. 2003; Roose et al. 2000; Vanmaercke et al. 2012a). Only one recent study, conducted in 28 catchments of Tunisia suggested the dominance of surface (rill/interrill) erosion (Jebari et al. 2010). This result was obtained through an analysis of correspondence between rainfall intensities and dominant erosion processes. However, additional knowledge regarding the sources of sediment (i.e., subsoil exported by gully and channel bank erosion vs. the superficial part of the soil exported by surface erosion) is necessary prior to defining appropriate management strategies to limit erosion at the catchment scale and to increase the reservoir lifetime (Haregeweyn et al. 2012; Vanmaercke et al. 2012b).

During the last few decades, fingerprinting techniques have been successfully applied to outline the sources of suspended sediments in rivers or the origin of riverbed, floodplain, and reservoir deposits in several regions of the world (e.g., Collins et al. 2010; Evrard et al. 2011; 
Walling 2005; Wasson et al. 2010). This technique is often used to identify the contribution of different land use types (Nicholls 2001), lithologies (Russell et al. 2001) or subcatchments (Walling 2005) to the sediment supply at the catchment scale. An overview of the diversity of potential tracing capabilities of various fields of applications with respect to the timescale, spatial scale and grain size is provided by D'Haen et al. (2012). The use of fingerprinting techniques based on radionuclides $\left({ }^{137} \mathrm{Cs}\right.$ in particular) alone or in combination with other tracers has proven to be effective in discriminating between subsoil and topsoil sources (e.g., Juracek and Ziegler 2009; Owens 1999; Smith et al. 2012). For example, Zhang and Walling (2005) showed that the magnitude of the ${ }^{137}$ Cs activity detected within the upper section of a sediment core collected in a lake or a reservoir can provide information on the relative contribution of surface and subsurface sources. Due to the lack of ${ }^{137} \mathrm{Cs}$ fallout during the post-Chernobyl period, ${ }^{137} \mathrm{Cs}$ is an appropriate tracer for investigating the origin of sediment accumulated in a reservoir after 1986.

This discrimination between surface and subsurface sources provides important quantitative information on the contribution of various processes that deliver sediment within a catchment. Surface sources can be associated with interrill or rill erosion, whereas subsurface sources are mobilised by gully or channel erosion processes.

The presence of fallout radionuclides in significant and measurable quantities in the soils of this region (e.g., Baggoura et al. 1998) enables the use of the fingerprinting technique to quantify the contribution of dominant erosion processes to reservoir deposits and their evolution since the reservoir installation. Organic constituents (e.g., organic carbon) can also be evaluated as potential fingerprints. For example, Albergel et al. (2006) demonstrated that the majority of the organic matter found at two Tunisian dams (El Gouazine and Fidh Ali) originated from upstream soil sources, and this organic matter was not transformed in the recently accumulated sediment (approximately 10 years old in their studies).

In addition, although cores collected from natural lakes or artificial reservoirs have been previously analysed using fingerprinting techniques to identify sediment sources (i.e., Foster et al. 2007; He et al. 1996; Zhang et al. 1997), the influence of the number and location of cores collected within this type of deposition area remains to be further investigated. The objectives of this study are as follows: i) to apply the fingerprinting technique to determine the origin of the sediment and assess the contribution of various erosion processes at the scale of a cultivated catchment in Northern Tunisia, and ii) to provide guidelines that define the number and location of cores to be collected within small reservoirs by exploring the vertical and spatial variability of sediment deposits within an artificial reservoir. 


\section{Materials and methods}

\subsection{Study site}

The Kamech catchment $\left(2.63 \mathrm{~km}^{2}\right)$ is located in a hilly agricultural region of the Northern Cape Bon, Tunisia $\left(36.88^{\circ} \mathrm{N}, 10.88^{\circ}\right.$ E, Fig. 1). A small reservoir with an initial capacity of $140,000 \mathrm{~m}^{3}$ was built at the catchment outlet in 1993 and has been in operation since 1994. Kamech is an experimental catchment and lacks any erosion mitigation measures. The Kamech catchment is a part of the OMERE long-term hydro-meteorological observation programme (http://www.umr-lisah.fr/omere).

The mean interannual precipitation in the catchment is $650 \mathrm{~mm}$, and the mean interannual evapotranspiration ranges up to $1400 \mathrm{~mm}$. Annually ploughed croplands occupy $70 \%$ of the catchment area and mainly occur on slopes of $<15 \%$. Cereals (wheat, barley, and oats) are the dominant crops and are cultivated in rotation with leguminous crops (chickpeas and beans). The remaining $30 \%$ of the catchment area consists of dwellings, gully and channels features, and Mediterranean scrublands. Two main areas of scrubland are present in the catchment. The first area corresponds to outcrops of sandstone bars locally covered by very shallow soils. Soil export from this area can therefore be neglected. The second scrubland area corresponds to non-cultivated steep slopes located in the vicinity of gullies or channels. It covers approximately $10 \%$ of the catchment area and may be prone to soil export because of occasional overgrazing. Therefore, only this second scrubland area was considered as a potential sediment source and was sampled in the framework of this study.

The mean field size is relatively small ( $0.5 \mathrm{ha})$, with $40 \%$ of the fields having a surface area between 0.2 and 0.3 ha. According to the FAO classification (2006), the soil types observed within the catchment are Calcic Cambisols (63.5\%), Regosols (25.5\%), Eutric Regosols (9.6\%) and Chromic Vertisols (1.4\%). Cropland predominantly covers Calcil Cambisols whereas gully and channel features predominantly cover Regosols. The majority of these soils are characterised by a high clay content (between 25 and $45 \%$ when using laser analysis and between 30 and $70 \%$ when using the pipette sampling method) and a low stoniness (less than $10 \%$ ). The bedrock mainly consists of marls and sandstone bars oriented in a southwest to northeast direction. The morphology and soil type in the catchment are the result of the geological setting such that the soils predominantly vary in a direction perpendicular to the sandstone bar outcrops (i.e., the SE-NW direction). Detailed maps showing the topography and soil types in Kamech are shown in Raclot and Albergel (2006). 
176 The outlet reservoir has an elongated shape with a single major water supply that drains more than $90 \%$ of the catchment area. A scour valve for sediment flushing from the reservoir was not constructed, and because overflows are negligible, almost all of the sediment originating from the catchment is trapped within the reservoir. The drainage network has intermittent flow discharge and water in the lake is clear during inter-storm periods.

During the period 1994-2008, the estimated mean annual sediment yield based on several lake sedimentation surveys was approximately $15 \mathrm{t}^{-h^{-1}} \cdot \mathrm{year}^{-1}$; and 11 significant runoff events (runoff $>1 \mathrm{~mm}$ ) occurred each year on average, among which only two events exceeded 10 $\mathrm{mm}$. The accumulated length of the gully and channel features was approximately $20 \mathrm{~km}$ in 2010 with an estimated annual linear progression of less than $0.2 \%$ between 1974 and 2010 based on aerial photography.

\subsection{Soil and sediment sampling}

Soil samples representative of the potential sediment source areas were collected in the catchment in September of 2009. All individual samples of source material corresponded to a composite of at least five subsamples collected within an approximate 5 m radius around the sampling point to increase the representativeness of the individual samples. The sampling efforts were concentrated in two areas: (i) the field surface (both croplands and scrublands) and (ii) gullies and channel banks. Areas showing evidence of erosion were given special consideration. For gully and channel sources, sampling was restricted to freshly cut sections in the bottom or the banks (when the features were deeper than $40 \mathrm{~cm}$ ). The sampling depth was $0-10 \mathrm{~cm}$ in croplands and $0-2 \mathrm{~cm}$ in scrubland environments. In total, 17 samples representative of the two source types were collected, i.e., between 3 and 4 samples km-2 for each source. This sampling density is greater than in the majority fingerprinting studies (e.g., Collins and Walling 2002; Collins et al. 2010; Juracek and Ziegler 2009; Owens and Walling 2002; Wasson et al. 2010) and was considered to be sufficient within the context of highly homogeneous soils. In addition, 2 reference samples were collected in areas without soil erosion or deposition, i.e., in flat scrubland areas enclosed within stone walls prior to 1990. Care was taken to ensure that the spatial coverage of all potential sources along the SE-NW direction was representative of the entire range of morphological and pedological conditions observed in the catchment (Fig. 1). At the end, 6 gully/channel samples came from Regosols and 3 from Calcic Cambisols. For the field surface samples, 5 came from cropland on Calcil Cambisols, 1 from cropland on Eutric Regosols and 2 from scrubland on Regosols. 
209 Furthermore, 17 sediment cores were collected from a boat during the same period (20092010) within the reservoir (Fig. 2a). Each core corresponded to the entire layer of lake sediment at the sampling locations. This completeness was confirmed by the presence of a more compact soil layer at the base of the core; in addition the core depths were consistent with data provided by topographical surveys conducted immediately after the reservoir construction. 13 of these cores ( $\mathrm{C} 1$ to $\mathrm{C} 13)$ were located along a downstream-to-upstream transect to capture the influence of the longitudinal core location within the sediment deposition area. Four additional cores were collected to verify that the transversal variability of the sediment core texture and composition was negligible compared to the longitudinal variability. This core sampling strategy was defined based on the concept that reservoir deposits are generally organised according to a longitudinal pattern resulting from both runoff inflow and density current effects (Remini and Remini 2003).

A single composite sample was prepared for each core to verify whether it could provide reliable and global information regarding the origin of the entire sediment sequence. The composite sample was prepared by extracting the central part of the core along its entire length. Subsamples corresponding to the sediment deposit sequences of the entire core were also prepared for cores $\mathrm{C} 2$ and C9. These cores were first divided into couplets using a complete stratigraphic description as reported by Ambers (2001). The couplets corresponded to single flood events, and the texture and thickness varied depending on the magnitude and the duration of the floods (Ambers 2001). The thicker couplets corresponding to single large flood event were readily identified and individually sampled. In contrast, the thinnest couplets composed of fairly homogeneous fine sediment corresponding to successive low flood events were difficult to isolate and thus regrouped before sampling. As a result, cores C2 and C9 were respectively divided into 20 and 11 continuous subsamples that were representative of a large range of flood conditions.

\subsection{Representativeness of the cores in terms of sediment volume}

The volume of sediment accumulated in a reservoir that can be associated with each core can be highly variable as a consequence of the variations in both the sediment thickness and core location patterns within a reservoir.

To determine the extent to which each core was representative of the sediment deposits, we employed both initial (1994) and recent (2009) bathymetric surveys using a GIS database. Thiessen polygons were constructed to interpolate between the cores (Fig. 2a). The representativeness of each core in terms of the sediment volume was then derived by 
calculating the difference between both bathymetric surfaces within each Thiessen polygon and dividing these volumes by the total deposit volume in the Kamech reservoir (Tab. 1). Figure $2 b$ illustrates that sediment accumulation depth is thicker close to the dam than in the upstream part of the reservoir.

\subsection{Choice of the fingerprinting properties}

Two types of fingerprint properties that are commonly considered to be the best tracers to differentiate surface from subsurface soil sources (e.g., Walling 2005) were analysed: (i) radionuclides and (ii) organic constituents.

The fallout radionuclide ${ }^{137} \mathrm{Cs}$ is particularly appropriate because it can be considered spatially homogeneous within small catchments, and it is typically characterised by a maximum concentration at the soil surface and a rapid decrease with depth (Wallbrink et al. 1999). Consequently, the ${ }^{137} \mathrm{Cs}$ activity in gully or channel-bank material tends to be substantially lower than in surface soils. Moreover, ${ }^{137} \mathrm{Cs}$ has been shown to behave conservatively throughout the sediment generation process (Motha 2002). In the context of sediments trapped in reservoirs built after $1990,{ }^{137} \mathrm{Cs}$ is likely to be the most reliable fallout radionuclide tracer because caesium fallout has been virtually null in North African countries since the Chernobyl accident in 1986. The burial process has no specific effect on caesium activity, and the direct comparison of its activity between sediment in the reservoir and material sources in the catchment area is feasible.

Organic constituents are also often used as tracers although their conservativeness during erosion and sediment delivery processes is less clear than for ${ }^{137} \mathrm{Cs}$ (Collins et al. 1997; Motha et al. 2002; Walling 2005). The magnitude of oxidation of eroded material during transport and after deposition may depend on the composition of particulate organic material (Lal 2006), as degradation rates ranging from $0 \%$ (Smith et al. 2001) to 100\% (Schlesinger 1995 in Lal 2006) have been reported. An analysis of recently accumulated sediments (approximately 10 years old) in two small reservoirs in Tunisia indicated that organic matter was not transformed during this period (Albergel et al 2006). This finding justifies the use of organic carbon as a potential tracer in this region.

\subsection{Soil and sediment analysis}

All soil and sediment samples were first described and then air-dried, hand-disaggregated and sieved through a 2-mm mesh. 
For the radionuclide measurements of each sample, a small quantity of soil ( 80 g) was placed in a counting box. The radionuclide concentrations $\left({ }^{210} \mathrm{~Pb}-\mathrm{xs},{ }^{210} \mathrm{~Pb},{ }^{234} \mathrm{Th},{ }^{226} \mathrm{Ra},{ }^{228} \mathrm{Ra}\right.$, ${ }^{228} \mathrm{Th},{ }^{40} \mathrm{~K}$ and ${ }^{137} \mathrm{Cs}$ ) were determined by gamma-spectrometry using low-background coaxial N- and P-type GeHP detectors (Canberra / Ortec) at the Laboratoire des Sciences du Climat et de l'Environnement (Gif-sur-Yvette, France). The efficiencies and background levels of the detectors were periodically controlled using internal and International Atomic Energy Agency (IAEA) soil and sediment standards (Evrard et al. 2010). All results were decay-corrected to the day of sampling. The uncertainty associated with radionuclide measurements was less than $5 \%$.

The total nitrogen (TN) and total organic carbon (TOC) contents of the soil and sediment were determined at the Laboratoire Bioemco (Paris, France) using the HCl-fumigation method and an ANCA-GSL CN analyser (PDZ Europa Ltd., Sandbach, UK) according to the method described by Harris et al. (2001). The analytical uncertainty of these measurements was less than $0.006 \%$ (Wilson and Fisher 2011). Stable isotope values of bulk carbon $\left(\delta^{13} \mathrm{C}\right)$ were also determined using the ANCA-GSL CN analyser coupled to an isotope ratio mass spectrometer (VG Sira 10).

The phosphorous contents $\left(\mathrm{P}_{2} \mathrm{O}_{5}\right)$ were measured at the Laboratoire d'Analyses des Sols d'Arras (Arras, France). For the $\mathrm{P}_{2} \mathrm{O}_{5}$ analyses, samples were dissolved using fluorhydric and perchloric acids $\left(\mathrm{HF}-\mathrm{HClO}_{4}\right)$ and analysed according to the method described by Ciesielski et al. (1997). Samples of approximately $0.250 \mathrm{~g}$ of soil sieved to $250 \mu \mathrm{m}$ were dosed by plasma emissions in photonic mode (ICP-Atomic Emission Spectroscopy).

After the preliminary destruction of organic matter and dispersion of soil particles, the grainsize distribution was determined based on the principle of laser diffraction using a Beckman Coulter LS 13320 particle size analyser at the Laboratoire Géosciences Montpellier (Montpellier, France). This device is equipped with an agitator and adjustable ultrasonicator to maintain uniform suspensions, which enables the analysis of particles with diameters between 0.375 and $2000 \mu \mathrm{m}$. Typical grain-size fractions (clay $<2 \mu \mathrm{m}, 2 \mu \mathrm{m}<$ silt $<50 \mu \mathrm{m}$ and $50 \mu \mathrm{m}<$ sand $<2 \mathrm{~mm}$ ) and the specific surface area $\left(\mathrm{SSA}, \mathrm{m}^{2} / \mathrm{m}^{3}\right)$ were derived from the obtained laser diffraction data.

Rock-Eval analyses were performed on six sediment samples corresponding to different depth layers of core $\mathrm{C} 2$ at the Département de Géologie of the Faculty of Sciences of Tunis (Tunisia). Rock-Eval analyses allow for the detection of the type, thus the origin, of organic carbon (terrestrial source vs. reservoir source). Approximately $100 \mathrm{mg}$ of the sediment core 
sample was placed in a Rock-Eval 6 analyser, and the results were interpreted based on a Van-Krevelen-type diagram (Espitalié et al. 1985).

\subsection{Sediment fingerprinting using a mixing model}

Differences in the particle size compositions between sediment core and source material were corrected to avoid potential variations that could have affected the fingerprint properties during sediment delivery due to the grain-size selectivity of sediment mobilisation, transport and deposition processes (Collins et al. 1997). He and Walling (1996) tested the particle size effects on the adsorption of ${ }^{137} \mathrm{Cs}$ on soils and sediments and showed that ${ }^{137} \mathrm{Cs}$ content can be closely represented by a power function of the specific surface areas of the samples with exponent values varying between 0.6 and 0.8 . In our study, the correction was performed using this power function with an exponent value of 0.7 . Each soil source (i.e., surface topsoil and gully/channel bank) was subsequently characterised by its mean concentration/activity and the standard deviation of each of its fingerprint properties.

The ability of each potential fingerprinting property to discriminate between the potential soil sources was investigated by conducting a non-parametric Kruskal-Wallis $H$-test. The null hypothesis stating that measurements of fingerprint properties exhibit no significant differences between source categories was rejected as soon as the $H$-test statistics reached the fixed critical threshold (typically 0.05).

A selection procedure using a stepwise discriminant function analysis (SDFA) was performed to identify the optimal combination of fingerprint properties based on the set of discriminating properties that successfully passed the Kruskal-Wallis $H$-test. As suggested by Collins and Walling (2002), the minimisation of Wilks' lambda was used as a stepwise selection algorithm to identify the set of parameters that, once combined, were able to correctly and optimally distinguish $100 \%$ of the source samples. Wilks' lambda is equal to one when all of the group means are equal. Fingerprinting properties providing a good discrimination of different sources are associated with low lambda values.

All tracer properties suspected of non-conservativeness during the erosion process or after deposition were removed from further analysis. ${ }^{210} \mathrm{~Pb}$-xs was also removed because the ${ }^{210} \mathrm{~Pb}-$ $\mathrm{xs}$ activity in the lake sediments could not be associated with the ${ }^{210} \mathrm{~Pb}$ - $\mathrm{xs}$ content of the source material alone because the direct fallout to the lake surface with rainfall is continuous. A multivariate Monte Carlo mixing model was then used to account for the actual variability of the fingerprinting properties measured in each source. By assuming a normal distribution for each fingerprinting property and source, a series of 10,000 random positive numbers was 
generated from these distributions and used to estimate the relative contribution of the potential sources in the sediment samples. Such a procedure allowed for the calculation of 95\% confidence intervals. A detailed description of this procedure is provided by Evrard et al. (2011).

Because the conservativeness of organic constituents is not absolutely certain, we chose to derive source apportionment based on radionuclides only and used organic constituents as complementary tracers in a second step to test whether the addition of those tracers confirmed the results of the first step.

\section{Results}

\subsection{Grain-size distribution of the Kamech sources and reservoir deposits}

Textural information for both the source material and reservoir deposit samples is provided in

Table 1. The grain-size fraction shows very small differences between the two potential sources as well as within each source. This result confirms that soils are highly homogeneous within the studied catchment.

In contrast, the textural analysis of all cores revealed a grain-size distribution gradient in the reservoir with an increasing proportion of finer sediment fractions in the cores with decreasing distance to the dam (Tab. 1). Sand particles were only found in the reservoir deposits near the stream outlet, whereas the cores collected in the vicinity of the dam were exclusively composed of clay and silt particles. This deposition pattern was consistent with the fact that sediment tends to become finer grained when being deposited further downstream in a reservoir (Morris and Fan 1997).

Two deposition areas were delineated within the reservoir based on the textural analysis. The first deposition area corresponds to the downstream region of the reservoir (e.g., close to the dam) and includes cores C1 to C5. This area is characterised by a homogeneous textural composition comprising very fine particles and a negligible sand fraction. This area contains approximately $75 \%$ of the total volume of sediment deposits in the reservoir as deduced from the estimated representativeness of the individual cores ( $\mathrm{C} 1$ to $\mathrm{C} 5$, see Tab. 1). The second deposition area corresponds to the upstream region of the reservoir and includes cores C6 to C13. The contribution of the sand fraction in this region varies from 5 to $35 \%$ and increases with increasing distance to the dam. This less homogeneous area contains $25 \%$ of the total volume of the sediment deposits. 


\subsection{Fingerprinting properties of potential soil sources and sediment core samples}

The profile variations of the specific surface area and main fingerprint properties (prior to grain-size correction) were determined for cores C2 and C9 as shown in Figure 3. A similar trend in the concentrations of the different fingerprint properties was observed in each core. Overall, the fingerprint properties were less variable in core $\mathrm{C} 2$ than in core $\mathrm{C} 9$, in which the concentrations of both ${ }^{137} \mathrm{Cs}$ and TOC were observed to decrease with depth. The diminution of this property decrease for C9 will not be mitigated by a grain-size correction because the specific surface area did not show a decreasing trend.

Scrubland (restricted to areas showing evidence of erosion) and cropland topsoil samples were considered to be one distinct source of surface sediment because they showed similar fingerprinting properties values. The qualitative analysis of the fingerprinting properties measured in the different soil sources and in the composite sediment core samples collected in the reservoir deposits (Tab. 1) provided general insight into the origin of the sediment at the outlet of the Kamech catchment.

As expected, ${ }^{137} \mathrm{Cs}$ provided a good level of discrimination between the surface topsoil material (with activities systematically greater than $2.2 \mathrm{~Bq} \cdot \mathrm{kg}^{-1}$ ) and the deep soil material originating from gullies and channel banks $\left(<0.8 \mathrm{~Bq} \cdot \mathrm{kg}^{-1}\right)$. In the core samples, the ${ }^{137} \mathrm{Cs}$ concentrations ranged between 0.9 and $3.9 \mathrm{~Bq} \cdot \mathrm{kg}^{-1}$ (Tab. 1). A simple analysis using the raw data showed that the bulk of the core sediment was supplied by soil surface erosion in the cores located near the dam, whereas the contribution of topsoil and subsoil sources was more balanced for the upstream cores. TOC analyses corroborated these findings.

\subsection{The optimal combination of fingerprinting properties and uncertainty assessment}

Although five radionuclides passed the Kruskal-Wallis test (Tab. 2), four of them were rejected due to evidence of non-conservative behaviour, i.e., their concentrations were higher in sediment than in both sources. Finally, only ${ }^{137} \mathrm{Cs}$ was retained as a tracer. TOC was also identified as a potentially discriminant property, and therefore, its use was tested in association with ${ }^{137} \mathrm{Cs}$ in the mixing model (Tab. 3) in a second phase of the analysis.

The outputs of the Monte Carlo mixing model based on 10,000 simulations consistently showed a standard deviation of $\pm 2 \%$. therefore, we present only the mean values provided by this model in the remaining sections. 


\subsection{Fingerprinting sediment sources in cores $\mathrm{C} 2$ and $\mathrm{C} 9$}

The sediment sources were derived for both composite core samples, and a sequence of subsamples collected at small vertical intervals within cores C2 and C9. These subsamples corresponded to the succession of one or more storm events since the creation of the artificial reservoir. The mixing models using ${ }^{137} \mathrm{Cs}$ only or ${ }^{137} \mathrm{Cs}$ in association with TOC showed very similar results (Fig. 4). Differences in the sediment source apportionment were not significant and were consistently less than $2 \%$ for all subsamples, i.e., on the same order of magnitude as the precision of the mean value calculated by the Monte-Carlo procedure.

The results showed that the origin of the sediment estimated from the composite sample was consistent with the origin estimated for the entire sequence of subsamples. Therefore, the composite sample was shown to provide reliable information, which remains valid for the entire core, on the origin of sediment and associated erosion processes.

The subsample analysis of the sequence of sediment deposits within the cores (e.g., 20 sequences for 15 years in core C2) showed that the temporal variability in the sediment sources was low in each core. These results confirm the relevance of analysing a single composite sample for each core to obtain global information regarding the dominant erosion sources and processes that occurred within the catchment over several decades. The mixing model results showed a clear predominance of the surface topsoil source for core C2 (> 80\%), whereas sediment in core C9 was supplied by a more even combination of surface and subsurface/bank sources.

\subsection{Fingerprinting sediment sources in the 13 composite core samples}

Source sediment apportionments for the 13 composite core samples taken along the AA' transect were also evaluated using either ${ }^{137} \mathrm{Cs}$ only or ${ }^{137} \mathrm{Cs}$ in association with $\mathrm{TOC}$ as fingerprint properties. The differences between both types of results were again $<2 \%$ for all composite core samples with the exception of $\mathrm{C} 13$, in which difference was $6 \%$ (Fig. 5).

These results demonstrate the major effect of the location of the core sampling site within the reservoir deposit area. Similar results were obtained for cores C1 to C5 with a clear predominance of the surface topsoil contribution (between 80 and 100\%). For cores C6 to C13, which were more distant from the dam, the mixing model shows that a larger proportion of sediment was supplied by the gully-channel bank source (between 30 and $75 \%$ ). The variability of sediment sources is thus higher in the upstream area of the reservoir deposits than in the area closer to the dam, with a trend towards a higher gully-channel bank contribution with increasing distance from the dam. 
A global fingerprinting result for all the sediment deposits was established by calculating a weighted average of the source contribution derived from the 13 composite core samples with the representative sediment volume of each core as weighted value (see Tab 1). Based on this calculation, we obtained a global picture of the sources delivering sediment to the reservoir at the outlet of the Kamech catchment. This global value for the reservoir clearly demonstrated that the surface topsoil is the dominant source of sediment within the Kamech catchment and supplied $80 \%$ of the sediment to the outlet reservoir.

\section{Discussion}

\subsection{Spatial variability and core sampling optimisation}

The spatial variability of the sediment texture within the reservoir trends in an upstreamdownstream direction (Tab. 1). This result is in agreement with transport sedimentation selection processes, i.e., the sedimentation of suspended fine particles occurs by vertical silting in the quiescent downstream region of the reservoir. In contrast, the upstream part of the reservoir is characterised by a higher velocity, and the runoff inflow and deposition mainly affects the coarser grain-size particles by both vertical silting and bedload processes. The ${ }^{137} \mathrm{Cs}$ and TOC contents were also affected by the contrasting sedimentation processes in these two sedimentation areas (Tab. 1). This result is consistent with a study conducted on sediments of the Yesa reservoir in the Spanish Pyrenees showing that the distribution of radionuclides along a transect of bottom reservoir sediments from the delta to the dam was influenced by the sediment dynamics and flood events (Navas et al. 2011 ).

More surprisingly, the results of the mixing model (Figure 5) for the different cores proved to be dependent on their location in the reservoir. However, it is unlikely that the source of the deposited sediment changes across the reservoir, as both potential sources are not characterised by clearly distinct particle size distributions. The most convincing explanation is that the standard particle size correction factor based on the SSA derived from laser measurements failed to fully address this problem. Preliminary investigations on the effect of the exponent value on the grain-size correction function were conducted by testing values in the range $[0.5 ; 1]$. The global fingerprinting result for the entire reservoir was only slightly impacted by the exponent value, as the contribution of the surface source varied only from 78.9 to $83.9 \%$. Similarly, Figure 6 shows that the fingerprinting results for the cores located in the downstream part of the reservoir were not significantly affected. In contrast, cores collected in the upstream part of the reservoir were significantly affected. An exponent value of 1 provided slightly less pronounced differences between the downstream and upstream 
areas, although these differences remained excessively high for the correction to be consider satisfactory. The choice of the exponent value was clearly not the main reason for this failure, and the function itself should be questioned. SSA may fail because the assumption of spherical particles is clearly not systematically valid, and adsorption behaviour may be highly dependent on the nature of the minerals - especially in the finer fraction - and not only on their grain size. Additional research on the grain-size correction factor is required to improve the reliability of the fingerprinting technique using this type of tracers.

Zonation induced by transport sedimentation processes finally proved to be a key element for the interpretation of mixing model results and for establishing a core sampling strategy when using the standard particle size correction factor.

A comparison of the mixing model estimation derived from a weighted average of the 13 composite cores (reference value) and the results obtained for each core provides a mechanism for evaluating the relevance of the reservoir coring strategy and deriving important guidelines (location and number) for future core sampling optimisation. We calculated the absolute errors in the source apportionment for the following three core sampling strategies (Tab. 4): sampling of a single core in the downstream reservoir area, sampling of a single core in the upstream reservoir area, and sampling of two cores (one in each area).

This calculation shows that the sampling of a single core in the downstream reservoir area will lead to a mean absolute error of approximately $7.5 \%$ (in this case, generating an overestimation of the surface topsoil contribution), whereas the sampling of a single core in the upstream reservoir area will lead to a larger error of approximately $25 \%$ (i.e., an underestimation of the surface contribution) (see Tab. 4). For the core sampling strategy based on two cores - one in the downstream reservoir area and the other in the upstream reservoir area - we applied a weight equal to $75 \%$ for the core collected in the downstream area and a weight of $25 \%$ for the core collected in the upstream area to account for the volumetric representation of both deposition areas. This strategy provided a means of decreasing the absolute mean error to less than $4 \%$ and the maximum error to less than $10 \%$ in the studied catchment.

Based on this assessment, an optimised core sampling strategy for the Kamech reservoir deposits can be based on the collection of a single core in the downstream reservoir deposit area if a maximal source estimation error of $15 \%$ can be accepted. Otherwise, a maximal source estimation error of $10 \%$ can be obtained if we conduct a dual-core sampling strategy. 
We believe that such a result may be generalised to other small reservoirs in Tunisia even if the $75 \%-25 \%$ apportionment between fine sediment in the downstream part of the reservoir and coarse deposits in the upstream part of the reservoir found in Kamech remains to be verified in other reservoirs characterised by a different shape, for example. We also believe that a core sampling scheme that combines the collection of cores in both upstream and downstream parts of the deposits will provide small errors in the results, independent of the number of potential sediment sources. In the case of reservoirs characterised by multiple tributaries, we suggest that the analysis of a core in the downstream part of the reservoir be combined with that of one core for each upstream area influenced by each tributary.

Finally, we also determined the relevance of analysing a single composite sample for each core to obtain synthetic information on the main erosion sources and processes that occurred within the catchment over several decades. This result has important practical and financial implications for the future application of this method in a similar context (e.g., sediment deposits in small-catchment reservoirs built during the 1990s in Maghreb) because it simplifies the core sampling process due to a lower diameter requirement and permits costsavings, as only one sample must to be analysed for each core.

\subsection{On the ability to use TOC as tracer in recent North African reservoirs}

The use of multiple tracers in a mixing model allows for more reliable source apportionment than the use of only one tracer (Martinez-Carreras et al. 2008; Small et al. 2001; Walling et al. 1993). In this study, TOC was tested as a tracer in addition to fallout radionuclides. The combined use of ${ }^{137} \mathrm{Cs}$ and TOC provided results similar to those obtained using ${ }^{137} \mathrm{Cs}$ alone. This ability of TOC to be used as an additional tracer in this study can be explained by the specific context of recently built North African reservoirs (less than 20 years old). First, the autochthonous source of organic constituents was found to be negligible in a series of more than 20 modern reservoirs where very low values of dissolved $\mathrm{P}$ and $\mathrm{N}$ have been measured (Rahaingomanana 1998). Recent complementary analyses confirmed that the Kamech reservoir is characterised by low levels of dissolved $\mathrm{N}$ and $\mathrm{P}$. The terrestrial origin of TOC was also verified for the Kamech reservoir using Rock-Eval analysis conducted on upper, middle and bottom subsamples of core $\mathrm{C} 2$ (Fig. 7). This result was also corroborated by $\delta^{13} \mathrm{C}$ measurements conducted for all the C2 and C9 subsamples and the surface topsoil samples, as all of the values of $\delta^{13} \mathrm{C}$ ranged from -27 to $-26 \%$ which is indicative of the contribution of $\mathrm{C}_{3}$ photosynthetic pathway plants (i.e., wheat crop residues in this case). 
Moreover, terrestrial organic residues probably did not experience major changes via bacterial alteration during their settling and incorporation into the sediment because terrestrial higher plant debris had already been submitted to strong biotic as well as abiotic degradation under oxic conditions in soils (Vandenbroucke and Largeau 2007). In our study area, degradation during mobilisation and transport is also limited due to the very short sediment transport distances within the $2.63 \mathrm{~km}^{2}$ Kamech catchment.

548 Degradation during the sediment storage period was also proved to be limited as no clear 549 downcore decrease in the evolution of TOC was observed within the C2 core. This result is 550 consistent with other observations from oligotrophic lacustrine environments such as the Lac du Bouchet (France), for which Patience et al. (1995) reported a first-order kinetics of TOC degradation of $2.210^{-3} \mathrm{y}^{-1}$. A similar degradation rate within a 15-years-old reservoir such as Kamech would generate a relative decrease in the TOC concentration of less than $2.5 \%$. This low degradation rate is likely not valid for upstream deposits because C9 core showed a downcore trend of decreasing TOC values.

\subsection{Erosion processes and sediment source hierarchy at the catchment scale}

The determination of the sediment sources in the core samples collected in the Kamech catchment reservoir (Cape Bon, Tunisia) using a fingerprinting method showed that the surface topsoil delivered approximately $80 \%$ of the sediment to the Kamech catchment outlet over a period of 15 years. This result implies that surface erosion processes, including rill and interrill erosion, are the dominant processes at the catchment scale. This result is consistent with the rather low annual gully length progression observed in the catchment. It is also in agreement with the results obtained by Jebari et al. (2010), who calculated that interrill processes produced $83 \%$ of the erosion within the Kamech catchment based on a rainfall erosivity analysis. However, the results present here differ from the conclusions of several other erosion studies conducted in the Mediterranean region that indicate a predominance of gully erosion. One explanation for this difference may be that the low rates of sheet and rill erosion and the relatively large importance of gully erosion in the Mediterranean region have often been attributed to the high extent of stoniness and shallow depth of many Mediterranean soils (e.g. Poesen and Hooke 1997), which is not the case in the studied catchment.

The potential surface sediment sources in Kamech catchment include both cropland and scrubland except in the sandstone bar outcrops. However, there are several indications that topsoil in the cropland area is by far the most important sediment source. First, the scrubland area covers only $10 \%$ of the catchment surface, whereas the cropland area represents $70 \%$ of 
the catchment area. Second, all of the cropland areas are likely to provide sediment, whereas only very limited scrubland areas suffering from over-grazing must be considered as sediment sources. Finally, the continuous multi-scale monitoring of erosion over a 4-year period showed that the sediment yield measured at the outlet of a $0.16 \mathrm{~km}^{2}$ subcatchment in Kamech reached $22{\mathrm{t} . h a^{-1} \text {.year }}^{-1}, 75 \%$ of this material was supplied by cropland and $25 \%$ by gully banks and bottoms, and the contribution of scrubland source remained negligible (Sauvadet et al., 2012). These measurements strongly supported the results derived in this study from the mixing models.

We also observed a low variability in ${ }^{137} \mathrm{Cs}$ and TOC in the different couplets of core C2 and C9, although those couplets could be related to a large range of flood event conditions. This result suggests that flood conditions over the 15-year existence of the reservoir did not strongly affect the sediment origin in the Kamech catchment. I.e., no exceptional flood event during which gully/channel erosion processes would have become a predominant source could be identified in the Kamech catchment.

\section{Conclusions}

This study demonstrated the viability of the fingerprinting method for tracing sediment sources in recent (i.e. post-Chernobyl) small artificial reservoir deposits using both ${ }^{137} \mathrm{Cs}$ and TOC. Therefore, this method can be used to quantify the relative importance of hillslope surfaces versus gully-channel bank erosion processes in North African environments. Several other radionuclides or nutrients were also tested as potential tracers of sediment sources but they did not deliver good results. The explanation is either their non conservativeness during the transport and deposition processes or their poor efficiency in discriminating between subsoil and topsoil sources. The determination of the sediment origin in the core samples collected in the Kamech catchment reservoir (Cape Bon, Tunisia) revealed surface soil erosion as the dominant source of deposited material. These results differ from the conclusions of most erosion studies conducted in the Mediterranean region that show a predominance of gully erosion. This finding has important management implications because the implementation of conservation farming practices would be more efficient than gully treatment for erosion mitigation in agricultural catchments similar to the Kamech study site. The predominance of one source of erosion in a catchment may, however, depend on specific conditions that are not yet fully understood. The strategy applied here of collecting a series of sediment cores along a longitudinal transect within the outlet reservoir provided a means of investigating the potential representativeness of a single sediment core collected within the 
reservoir. Practical guidelines for conducting core sampling in small reservoirs were derived as follows: i) a composite core sample provides a good representation of the entire core length according to the homogeneity observed in the two sediment cores that were analysed in greater detail; ii) a two-core sampling strategy allows for the evaluation of source contributions with an error of less than $10 \%$ for the studied catchment. We also suggest adjusting the number of cores as a function of the number of main tributaries that supply material to the studied reservoir. This strategy developed and tested in the Kamech catchment can now be applied to the numerous existing reservoirs located in the Tunisian Ridge and Cape Bon areas. This region is affected by severe erosion, and it is crucial to determine the relative contributions of surface erosion and gully erosion in various contrasting catchments to address the controversial issue of outlining the dominant erosion process that deliver the bulk of sediment in this type of Mediterranean environment. This determination of the dominant erosion process should allow to propose management guidelines that are adapted for each catchment to control erosion.

Acknowledgements This study was financially supported by the IRD-DSF, SCAC of French embassy and a CNRS/DGRS exchange agreement (No. 24443) between France and Tunisia. This study was performed within the framework of the OMERE Observatory funded by INRA and IRD. We thank three anonymous reviewers for their insightful comments, which greatly improved this manuscript.

\section{References}

Albergel J, Boufaroua M, Pepin Y (1998) Bilan de l'érosion sur les petits bassins versants des lacs collinaires en climat semi-aride Tunisien. Bulletin Réseau Erosion 18:67-75

Albergel J, Collinet J, Pépin Y, Zante P, Nasri S, Boufaroua M, Droubi A, Merzouk A (2005) The sediment budgets of hill reservoirs in small catchments in North Africa and the middle East. Sediment Budgets 1, Book Series: IAHS Publ 291:323-331

Albergel J, Mansouri T, Zante P, Ben Mamou A, Abdeljaoued S (2006) Organic carbon in the sediments of hill dams in a semiarid Mediterranean area. In: Roose E, Lal R, Feller C, Barthès B, Stewart BA (eds) Soil erosion and carbon dynamics. Taylor et Francis, Boca Raton, pp 289-299

Ambers RKR (2001) Using the sediment record of western Oregon flood-control reservoir to assess the influence of storm history and logging on sediment yield. Journal of hydrology 244:181-200 
Baggoura B, Noureddine A, Benkrid M (1998) Level of natural and artificial radioactivity in Algeria. Appl Radiat Isotopes 49(7): 867-873

Ben Cheikha L, Gueddari M (2008) Le basin versant de Jannet (Tunisie): évaluation des risques d'érosion hydrique. $\quad$ M@ppemonde 90

(2008.2). http://mappemonde.mgm.fr/num18/articles/art08202.pdf

Bouchnak, H, Felfoul MS, Boussema MR, Snane MH (2009) Slope and rainfall effects on the volume of sediment yield by gully erosion in the Souar lithologic (Tunisia). Catena $78(2): 170-177$

Cantón Y, Solé-Benet A, de Vente J, Boix-Fayos C, Calvo-Cases A, Asensio C, Puigdefábregas J (2011) A review of runoff generation and soil erosion across scales in semiarid south-eastern Spain. J Arid Environ 75(12):1254-1261

Ciesielski H, Proix N, Sterckeman T (1997) Détermination des incertitudes liées à une méthode de mise en solution des sols et des sédiments par étude inter-laboratoire. Analysis 25:188-192

Collinet J, Zante P (2005) Analyse du ravinement de bassins versants à retenues collinaires sur sols à fortes dynamiques structurales (Tunisie). Géomorphologie 1: relief, processus, environnement 1:61-74

Collins AL, Walling DE (2002) Selecting fingerprint properties for discriminating potential suspended sediment sources in river basins. J Hydrol 261:218-244

Collins AL, Walling DE, Leeks GJL (1997) Source type ascription for fluvial suspended sediment based on a quantitative composite fingerprinting technique. Catena 29:1-27

Collins AL, Walling DE, Webb L, King P (2010) Apportioning catchment scale sediment sources using a modified composite fingerprinting technique incorporating property weightings and prior information. Geoderma 155:249-261

Desprats JF, Raclot D, Rousseau M, Cerdan O, Garcin M, Le Bissonnais Y, Ben Slimane A, Fouche J, Monfort-Climent D (2012) Satellite imagery mapping of linear erosion features. Land Degradation \& Development. doi: 10.1002/ldr.1094

D'Haen K, Verstraeten G, Degryse P (2012) Fingerprinting historical fluvial sediment fluxes. Progress in Physical Geography 36:154-186

de Vente J, Poesen J, Bazzofi P, Van Rompaey A, Verstaeten G (2006) Predicting catchment sediment yield in Mediterranean environments: the importance of sediment sources and connectivity in Italien drainage basins. Earth Surf Proc Land 31:1017-1034 
de Vente J, Poesen J, Verstraeten G, Van Rompaey A, Govers G (2008) Spatially distributed modelling of soil erosion and sediment yield at regional scales in Spain. Global and Planetary Change 60:393-415

EEA (2000) Down to earth: Soil degradation and sustainable development in Europe, A challenge for the 21 st century. Environmental issues series 16. Office for Official Publications of the European Communities, Luxembourg

Espitalié J, Deroo G, Marquis F (1985) La pyrolyse Rock-Eval et ses applications. Revue de l’Institut Francais du Petrole, Part I 40:563-578, Part II 40:755-784; Part III 41:73-89

Evrard O, Némery J, Gratiot N, Duvert C, Ayrault S, Lefèvre I, Poulenard J, Prat C, Bonté P, Esteves M (2010) Sediment dynamics during the rainy season in tropical highland catchments of central Mexico using fallout radionuclides. Geomorphology 124:42-54

Evrard O, Navratil O, Ayrault S, Ahmadi M, Némery J, Legout C, Lefèvre I, Poirel A, Bonté P, Esteves M (2011) Combining suspended sediment monitoring and fingerprinting to determine the spatial origin of fine sediment in a mountainous river catchment. Earth Surf Proc Land 36:1072-1089

Foster IDL, Boardman J, Keay-Brigth J (2007) Sediment tracing and environmental history for two small catchments, Karoo Uplands, South Africa. Geomorphology 90:126-143

Haregeweyn N, Melesse B, Tsunekawa A, Tsubo M, Mesheshe D, Babullo Balana B (2012) Reservoir sedimentation and its mitigating strategies: a case study of Angered reservoir (NW Ethiopia). Journal of Soils and Sediments 12:291-305

Harris D, Horwath WR, Kessel CV (2001) Acid fumigation of soils to remove carbonates prior to total organic carbon or carbon-13 isotopic analysis. Soil Sci Soc Am J 65:18531856

He Q, Walling DE (1996) Interpreting particle size effects in the adsorption of ${ }^{137} \mathrm{Cs}$ and unsupported ${ }^{210} \mathrm{~Pb}$ by mineral soils and sediments. J Environ Radioactivity 30:117-137

He Q, Walling DE, Owens PN (1996) Interpreting the 137Cs profiles observed in several small lakes and reservoirs in southern England. Chem Geol 129:115-131.

Hentati A, Kawamura A, Amaguchi H, Iseri Y (2010) Evaluation of sedimentation vulnerability at small hillside reservoirs in the semi-arid region of Tunisia using the SelfOrganizing Map. Geomorphology 122:56-64

Jebari S, Berndtsson R, Bahri A, Boufaroua M (2010) Spatial soil loss risk and reservoir siltation in semi-arid Tunisia. Hydrolog Sci J 55(1):121-137

Juracek KE, Ziegler AC (2009) Estimation of sediment sources using selected chemical tracers in the Perry lake basin, Kansas, USA. Int J Sediment Res 24(1):108-125 
Lal R (2006) Influence of soil erosion on carbon dynamics in the World. In: Roose E, Lal R, Feller C, Barthès B, Stewart BA (eds) Soil erosion and carbon dynamics. Taylor et Francis, Boca Raton, pp 23-35

Lesschen JP, Cammeraat LH, Nieman T (2008) Erosion and terrace failure due to agricultural land abandonment in a semi-arid environment. Earth Sur Proc Land 33(10):1574-1584

Martinez-Carreras N, Gallart F, Iffly JF, Pfister L, Walling DE, Krein A (2008) Uncertainty assessment in suspended sediment fingerprinting based on tracer mixing models: a case study from Luxembourg. In: Schmidt J, Cochrane T, Phillips C, Elliot S, Davies T, Basher L (eds) Sediment dynamics in changing environments. IAHS Publ 325, Wallingford, pp 94-105

Mougou R, Mansour M, Vacher J, Cellier P (2006) La valorisation agricole de l'eau des lacs collinaires: cas du lac collinaire Kamech (Tunisie). Sécheresse 17(3):385-90

Morris GL, Fan J (1997) Reservoir Sedimentation Handbook. McGraw-Hill, New York

Motha JA, Wallbrink PJ, Hairsine PB, Grayson RB (2002) Tracer properties of eroded sediment and source material. Hydrol Process 16:1983-2000

Navas A, Valero-Garcés B, Gaspar L, Palazón L (2011) Radionuclides and stable elements in the sediments of the Yesa Reservoir, Central Spanish Pyrenees. Journal of Soils and Sediments 11:1082-1098

Nicholls DJ (2001) The source and behaviour of fine sediment deposits in the River Torridge Devon and their implications for salmon spawning. Unpublished $\mathrm{PhD}$ thesis, University of Exeter

Owens PN, Walling DE (2002) Changes in sediment sources and floodplain deposition rates in the catchment of the River Tweed, Scotland, over the last 100 years: The impact of climate and land use change. Earth Surf Proc Land 27:403-423

Owens PN, Walling DE, Leeks GJL (1999) Use of floodplain sediment cores to investigate recent historical changes in overbank sedimentation rates and sediment sources in the catchment of the River Ouse, Yorkshire, UK. Catena 36:21-47

Owens PN, Batalla RJ, Collins AJ, Gomez B, Hicks DM, Horowitz AJ, Kondolf GM, Marden M, Page MJ, Peacock DH, Petticrew EL, Salomons W, Trustrum NA (2005) Finegrained sediment in river systems: environmental significance and management issues. River Res Appl 21:693-717

Patience AJ, Lallier-Vergès E, Sifeddine A, Albéric P, Guillet B (1995) Organic fluxes and early diagenesis in the lacustrine environment: the superficial sediments of the Lac du Bouchet (Haute Loire, France). In: Lallier-Vergès E, Tribovillard N, Bertrand P (eds) 
Organic Matter Accumulation: The Organic Cyclicities of the Kimmeridge Clay Formation (Yorkshire, G.B.) and the Recent Maar Sediments (Lac du Bouchet). Lecture Notes in Earth Sciences 57. Springer-Verlag, Heidelberg, pp 145-156

Pimentel D, Harvey C, Resosudarmo P, Sinclair K, Kurz D, McNair M, Crist S, Shpritz L, Fitton L, Saffouri R, Blair R (1995) Environmental and economic costs of soil erosion and conservation benefits. Science, new series 267(5201):1117-1123

Poesen J, Hooke J (1997) Erosion, flooding and channel management in Mediterranean environments of southern Europe. Progress in Physical Geography 21:157-199

Poesen J, Nachtergaele J, Verstraeten G, Valentin C (2003) Gully erosion and environmental change: importance and research needs. Catena 50(2/4):91-133

Raclot D, Albergel J (2006) Runoff and water erosion modelling using WEPP on a Mediterranean cultivated catchment. Phys Chem Earth 31(17):1038-1047

Rahaingomanana N (1998) Caractérisation géochimique des lacs collinaires de la Tunisie semi-aride et régulation géochimique du phosphore. $\mathrm{PhD}$ thesis, Univ. Montpellier I

Remini W, Remini B (2003) La sédimentation dans les barrages de l'Afrique du nord. Larhyss Journal 2: 45-54

Roose E, Chebbani R, Bourougaa L (2000) Ravinement en Algérie, facteurs de contrôle, quantification et réhabilitation. Science et changements planétaires/ Sécheresse 11(4):317-326

Russell MA, Walling DE, Hodgkinson RA (2001) Suspended sediment sources in two small lowland agricultural catchments in the UK. J Hydrol 252:1-24

Sauvadet M, Raclot D, Ben Slimane A, Le Bissonnais Y (2012) Déterminisme du ruissellement et de l'érosion hydrique de la parcelle au versant en milieu méditerranéen marneux. Revue Marocaine des Sciences Agronomiques Vétérinaires 1:41-46. http://www.agrimaroc.org/index.php/Actes_IAVH2/article/view/282/248.

Schlesinger WH (1995) Soil respiration and changes in soil carbon stocks. In: Woodwell GM, Mackenzie FT (eds) Biotic Feedbacks in the Global Climate System. Oxford University Press, Oxford, pp 159-168

Small IF, Rowan JS, Franks SW (2002) Quantitative sediment fingerprinting using a Bayesian uncertainty estimation framework. In: Dyer FJ, Thoms MC, and Olley JM (eds) Structure, Function and Management Implications of Fluvial Sedimentary Systems. IAHS Publ 276, Wallingford, pp 443-450 
Smith SV, Renwick WH, Buddemeier RW, Crossland CJ (2001) Budgets of soil erosion and deposition for sediments and sedimentary organic carbon across the conterminous United States. Global Biogeochem Cy 15:697-707

Smith HG, Sheridan GJ, Nyman P, Child DP, Lane PNJ, Hotchkis MAC, Jacobsen GE (2012) Quantifying sources of fine sediment supplied to post-fire debris flows using fallout radionuclide tracers. Geomorphology 139-140:403-415

Vandenbroucke M, Largeau C (2007) Kerogen origin, evolution and structure. Organic Geochemistry 38:719-833

Vanmaercke M, Poesen J, Verstraeten G, Maetens W, de Vente J (2012a) Sediment yield as a desertification risk indicator. Science of the Total Environment 409:1715-1725

Vanmaercke M, Maetens W, Poesen J, Jankauskas B, Jankauskiene G, Verstraeten G, de Vente J (2012b) A comparison of measured catchment sediment yields with measured and predicted hillslope erosion rates in Europe. J Soils Sediments 12:586-602

Wallbrink PJ, Murray AS, Olley JM (1999) Relating suspended sediment to its original soil depth using fallout radionuclides. Soil Sci Soc Am J 63:369-378

Walling DE (2005) Tracing suspended sediment sources in catchments and river systems. Sci Total Environ 344:159-184

Walling DE, Woodward JC, Nicholas AP (1993) A multi-parameter approach to fingerprint suspended-sediment sources. In: Peters NE, Hoehn E, Leibundgut C., Tase N, Walling DE (eds) Tracers in hydrology. IAHS Publ 215, Wallingford, pp 329-338

Wasson RJ, Furlonger L, Parry D, Pietsch T, Valentine E, Williams D (2010) Sediment sources and channel dynamics, Daly River, Northern Australia. Geomorphology 114:161-174

Wilson JP, Fischer WW (2011) Geochemical Support for a Climbing Habit within the Paleozoic Seed Fern Genus Medullosa. Int J Plant Sci 172(4):586-598

Zhang X, Walling DE (2005) Landscape and Watershed Processes: Characterizing Land Surface Erosion from Cesium-137 Profiles in Lake and Reservoir Sediments. J Environ Qual 34:514-52

Zhang X, Walling DE, Quine TA, Wen A (1997) Use of reservoir deposits and caesium-137 measurements to investigate the erosional response of a small drainge basin in the rolling loess plateau region of China. Land Degrad Dev 8:1-96 
Fig. 1 Location and aerial view of the Kamech catchment. The source sampling sites are shown.

Fig. 2 Core sampling locations within the Kamech reservoir and Thiessen polygons outlines based on the cores $\mathrm{C} 1$ to $\mathrm{C} 13$ (a); and the AA' longitudinal section view of the sediment deposit depths with the locations of the13 associated cores (b).

Fig. 3 Downcore variations in the specific surface area and selected fingerprint properties for cores $\mathrm{C} 2$ and core C9

Fig. 4 Surface topsoil apportionment derived using the mixing model - either with the combination of caesium and carbon or with caesium only - for the sequences of the two cores C2 and C9 collected in the Kamech reservoir. The value derived from the composite core sample is also presented. Note that the complementary contribution of surface topsoil erosion is provided by gully or channel-bank erosion.

Fig. 5 Surface topsoil apportionment in the Kamech catchment according to the core location along the AA' transect. The weighted average for the 13 composite core samples is also represented. Note that the complementary contribution of surface topsoil erosion is provided by gully or channel-bank erosion.

Fig. 6 Sensitivity of the surface source derived from fingerprinting results to the exponent value in the grain-size correction function. The result without any grain-size correction is also depicted.

Fig. 7 Kerogen type and evolution paths (arrows) in the van Krevelen diagram of HI vs. OI. Kerogen types I, II, and III correspond to waxy organic matter, algal organic matter and vascular plant organic matter, respectively. 
Table 1 Average and standard deviation concentrations/activities of textural and potential fingerprinting properties measured in the soil sources and sediment core samples collected in the Kamech catchment and in its reservoir. Representativeness of each core in terms of sediment deposit volume in Kamech reservoir is also mentioned.

\begin{tabular}{|c|c|c|c|c|c|c|c|c|c|c|c|c|c|c|c|c|c|c|}
\hline \multicolumn{2}{|c|}{$\begin{array}{l}\text { Fingerprint } \\
\text { Properties }\end{array}$} & $\begin{array}{l}\text { Number } \\
\text { of } \\
\text { samples }\end{array}$ & $\begin{array}{l}\text { Clay } \\
{[0-2} \\
\mu \mathrm{m}]\end{array}$ & $\begin{array}{c}\text { silt } \\
{[2-50} \\
\mu \mathrm{m}]\end{array}$ & $\begin{array}{c}\text { sand } \\
{[50-2000} \\
\mu \mathrm{m}]\end{array}$ & $\begin{array}{l}{ }^{210} \mathrm{~Pb}-\mathrm{Xs} \\
(\mathrm{Bq} / \mathrm{Kg})\end{array}$ & $\begin{array}{c}{ }^{210} \mathrm{~Pb} \\
(\mathrm{~Bq} / \mathrm{Kg})\end{array}$ & $\begin{array}{c}{ }^{234} \mathrm{Th} \\
(\mathrm{Bq} / \mathrm{Kg})\end{array}$ & $\begin{array}{c}{ }^{226} \mathrm{Ra} \\
(\mathrm{Bq} / \mathrm{Kg})\end{array}$ & $\begin{array}{c}{ }^{228} \mathrm{Ra} \\
(\mathrm{Bq} / \mathrm{Kg})\end{array}$ & $\begin{array}{c}{ }^{228} \mathrm{Th} \\
(\mathrm{Bq} / \mathrm{Kg})\end{array}$ & $\begin{array}{c}\mathrm{K} \\
(\%)\end{array}$ & $\begin{array}{c}{ }^{137} \mathrm{Cs} \\
(\mathrm{Bq} / \mathrm{Kg})\end{array}$ & $\begin{array}{l}\text { TOC } \\
(\%)\end{array}$ & $\begin{array}{l}\mathrm{TN} \\
(\%)\end{array}$ & $\underset{(\%)}{\mathrm{P}_{-} \mathrm{P}_{2} \mathrm{O}_{5}}$ & $\begin{array}{c}\text { Core } \\
\text { distance } \\
\text { to the } \\
\text { dam }(\mathrm{m})\end{array}$ & $\begin{array}{l}\text { Core } \\
\text { representa- } \\
\text { tiveness } \\
(\%)\end{array}$ \\
\hline \multirow{3}{*}{\multicolumn{2}{|c|}{ References }} & 2 & 30.2 & 67.7 & 2.1 & 44.3 & 59.9 & 18.9 & 15.7 & 22.9 & 22 & 1 & 7.1 & 1.6 & 0.16 & 0.07 & & \\
\hline & & & \pm & \pm & \pm & \pm & \pm & \pm & \pm & \pm & \pm & \pm & \pm & \pm & \pm & \pm & & \\
\hline & & & 1.2 & 1.4 & 2.6 & 37.1 & 44.9 & 10.5 & 7.8 & 12.3 & 11 & 0.3 & 0.4 & 0.6 & 0 & 0 & & \\
\hline \multirow[t]{6}{*}{ Sources } & $\begin{array}{c}\text { Surface } \\
\text { topsoil }\end{array}$ & 8 & 36.3 & 62.8 & 0.9 & 6.1 & 29.3 & 28.1 & 23.3 & 39.8 & 38.5 & 1.4 & 3.7 & 1.1 & 0.15 & 0.15 & & \\
\hline & & & \pm & \pm & \pm & \pm & \pm & \pm & \pm & \pm & \pm & \pm & \pm & \pm & \pm & \pm & & \\
\hline & & & 6 & 5.9 & 0.6 & 6.1 & 4.1 & 7.1 & 5.8 & 10.6 & 10.2 & 0.3 & 1.5 & 0.1 & 0 & 0 & & \\
\hline & $\begin{array}{c}\text { Gully or } \\
\text { channel } \\
\text { bank }\end{array}$ & 9 & 27.4 & 71.8 & 0.8 & 0.3 & 26.9 & 32.6 & 29.1 & 47.1 & 46.5 & 1.7 & 0.2 & 0.5 & 0.11 & 0.16 & & \\
\hline & & & \pm & \pm & \pm & \pm & \pm & \pm & \pm & \pm & \pm & \pm & \pm & \pm & \pm & \pm & & \\
\hline & & & 2.3 & 3.2 & 1 & 0.9 & 2.4 & 2.2 & 2.3 & 3.8 & 3.6 & 0.2 & 0.4 & 0.1 & 0 & 0 & & \\
\hline \multirow[t]{13}{*}{ Cores } & $\mathrm{C} 1$ & $1 *$ & 34.3 & 65.5 & 0.2 & 24 & 51.3 & 37.6 & 27.5 & 52.2 & 53.6 & 1.9 & 3.4 & 0.89 & 0.16 & 0.17 & 63 & 30 \\
\hline & $\mathrm{C} 2$ & $1 *$ & 33.3 & 64.8 & 2 & 10.7 & 40 & 36.6 & 29.4 & 47.6 & 48.4 & 1.7 & 3 & 0.99 & 0.14 & 0.15 & 100 & 15.6 \\
\hline & C3 & $1 *$ & 30.3 & 68.2 & 1.4 & 10.9 & 37.3 & 35.4 & 26.5 & 49.1 & 49.9 & 1.7 & 3 & 1.1 & 0.16 & 0.16 & 137 & 10.7 \\
\hline & $\mathrm{C} 4$ & $1 *$ & 35.1 & 64.5 & 0.5 & 17.2 & 45.2 & 34 & 28.1 & 50.5 & 48.7 & 1.8 & 3.9 & 0.94 & 0.18 & 0.17 & 180 & 11.5 \\
\hline & C5 & $1 *$ & 29.6 & 69.2 & 1.2 & 9.8 & 37.2 & 35.8 & 27.5 & 47.8 & 47.8 & 1.7 & 2.9 & 1.21 & 0.16 & 0.15 & 220 & 8.3 \\
\hline & C6 & $1 *$ & \begin{tabular}{|l|}
17.6 \\
\end{tabular} & 71.9 & 10.5 & 7.4 & 33.8 & 37.6 & 26.5 & 46.4 & 45.3 & 1.7 & 1.9 & 0.58 & 0.1 & 0.16 & 255 & 6.5 \\
\hline & C7 & $1 *$ & 18.6 & 66.9 & 14.5 & 7.6 & 35.5 & 32.7 & 28 & 45.6 & 44.4 & 1.5 & 1.6 & 0.84 & 0.12 & 0.14 & 275 & 4.1 \\
\hline & $\mathrm{C} 8$ & $1 *$ & 18.6 & 62.5 & 18.9 & 0 & 28.2 & 30.5 & 28.6 & 43.1 & 42.6 & 1.5 & 1.8 & 0.85 & 0.12 & 0.13 & 293 & 1.6 \\
\hline & C9 & $1 *$ & 18.2 & 74.4 & 7.4 & 3.3 & 26.2 & 26.6 & 22.9 & 39.9 & 39.6 & 1.4 & 1.2 & 0.61 & 0.1 & 0.15 & 304 & 4 \\
\hline & $\mathrm{C} 10$ & $1 *$ & 21 & 70.4 & 8.6 & 0 & 28.6 & 32.3 & 27.5 & 41 & 41.3 & 1.5 & 1.1 & 0.56 & 0.09 & 0.14 & 312 & 2.6 \\
\hline & C11 & $1 *$ & 17.4 & 71.8 & 10.9 & 3.7 & 28.5 & 34.1 & 24.9 & 42.5 & 42.6 & 1.5 & 0.9 & 0.52 & 0.09 & 0.16 & 332 & 1.4 \\
\hline & $\mathrm{C} 12$ & $1 *$ & 15.5 & 69.1 & 15.4 & 0 & 29.8 & 30.7 & 28.2 & 42.2 & 42 & 1.5 & 1.2 & 0.8 & 0.11 & 0.15 & 385 & 1 \\
\hline & C13 & $1 *$ & \begin{tabular}{|l|}
10.8 \\
\end{tabular} & 55.8 & 33.4 & 0 & 31.2 & 33.9 & 29.8 & 45.2 & 46.1 & 1.6 & 1.1 & 1.1 & 0.14 & 0.16 & 449 & 2.7 \\
\hline
\end{tabular}

\footnotetext{
* composite sediment sample
} 
Table 2 Results of the Kruskal-Wallis H-test applied to the eleven potential fingerprint properties measured for the source soils collected in the Kamech catchment

\begin{tabular}{cc}
\hline Potential fingerprint & H-value \\
\hline${ }^{210} \mathrm{~Pb}-\mathrm{Xs}\left(\mathrm{Bq} \cdot \mathrm{Kg}^{-1}\right)$ & 5.79 \\
${ }^{210} \mathrm{~Pb}\left(\mathrm{~Bq} \cdot \mathrm{Kg}^{-1}\right)$ & 0.75 \\
${ }^{234} \mathrm{Th}\left(\mathrm{Bq} \cdot \mathrm{Kg}^{-1}\right)$ & $8.33 *$ \\
${ }^{226} \mathrm{Ra}\left(\mathrm{Bq} \cdot \mathrm{Kg}^{-1}\right)$ & $12.00 *$ \\
${ }^{228} \mathrm{Ra}\left(\mathrm{Bq} \cdot \mathrm{Kg}^{-1}\right)$ & $8.33 *$ \\
${ }^{228} \mathrm{Th}\left(\mathrm{Bq} \cdot \mathrm{Kg}^{-1}\right)$ & $9.48 *$ \\
$\mathrm{~K}(\%)$ & 6.50 \\
${ }^{137} \mathrm{Cs}\left(\mathrm{Bq} \cdot \mathrm{Kg}^{-1}\right)$ & $12.00 *$ \\
$\mathrm{TOC}(\%)$ & $11.34 *$ \\
$\mathrm{TN}(\%)$ & 5.56 \\
$\mathrm{P} \mathrm{O}_{5}(\%)$ & 3.89 \\
\end{tabular}

844

$845 *$ difference significant at $p=0.05$ 
1

2852

3853

4854

5

6

7

8

9

10

11

12

13

14

15

16

17

18

19

20

21

22

23

24

25

26

27

28

29

30

31

32

33

34

35

36

37

38

39

40

41

42

43

44

45

46

47

48

49

50

51

52

53

54

55

56

57

58

59

60

61

62

63

64

65

(

Table 3 Results of the stepwise discriminate function analysis use to identify the optimum fingerprint property combination

\begin{tabular}{c|cc}
\hline Fingerprint property added & Wilk's lambda & Cumulative \% of samples classified correctly \\
\hline${ }^{137} \mathrm{Cs}\left(\mathrm{Bq} \cdot \mathrm{Kg}^{-1}\right)$ & 0.2247 & 77.53 \\
$\mathrm{C}(\%)$ & 0.1123 & 100 \\
\hline
\end{tabular}


856

1857

2858

3859

4860

5861

6

7

8

9

10

11

12

13

14

15

16862

17

18

19

20

21

22

23

24

25

26

27

28

29

30

31

32

33

34

35

36

37

38

39

40

41

42

43

44

45

46

47

48

49

50

51

52

53

54

55

56

57

58

59

60

61

62

63

64

65

Table 4 Basic statistics on the absolute errors in the source contribution evaluation for the three core sampling strategies. The absolute error is evaluated relative to the source apportionment for the entire reservoir as derived from the combined 13 cores with a weighting proportional to their representativeness in terms of sediment volume. The absolute error is calculated for each core as the absolute difference between surface contribution derived from the core and the one derived from the combined 13 cores.

\begin{tabular}{|c|c|c|c|c|}
\hline Core sampling strategy & \multicolumn{4}{|c|}{ Absolute error (\%) } \\
\hline & Mean & Standard deviation & Minimum & Maximum \\
\hline One core in downstream reservoir area (N = 5) & 7.3 & 4.8 & 2.7 & 15.3 \\
\hline $\begin{array}{c}\text { One core in upstream reservoir area (N = 8) } \\
\text { Two cores: one in downstream reservoir area } \\
\text { with a 75\% weighting and one in upstream } \\
\text { reservoir area with a 25\% weighting ( } \mathrm{N}=40)\end{array}$ & 26.1 & 16.1 & 6.8 & 47.9 \\
\hline
\end{tabular}



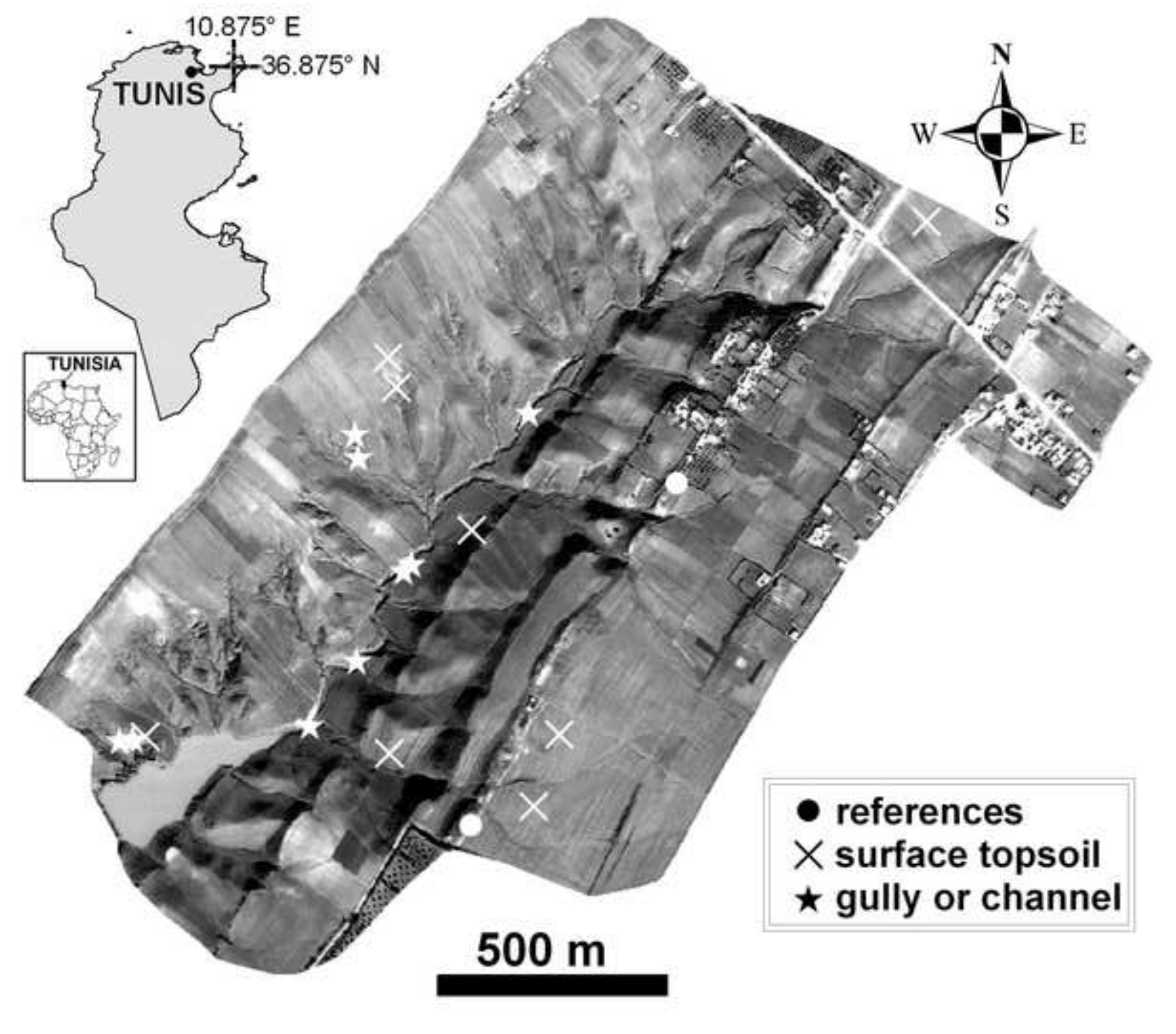

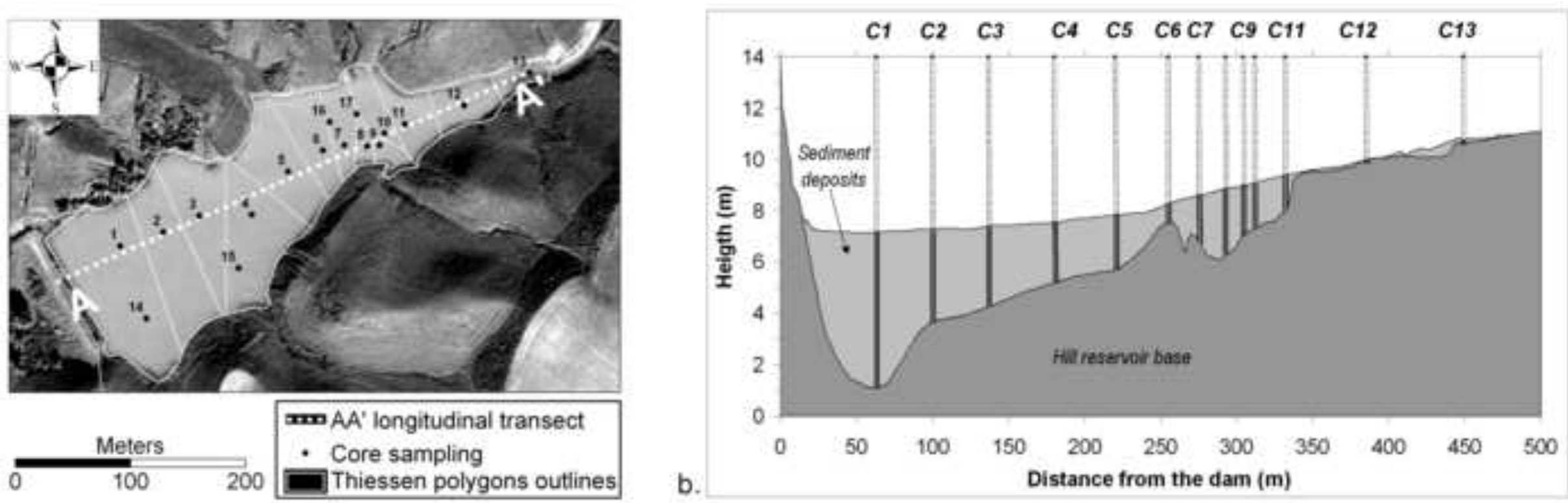

b. Distance from the dam (m) 


\section{CORE C2}
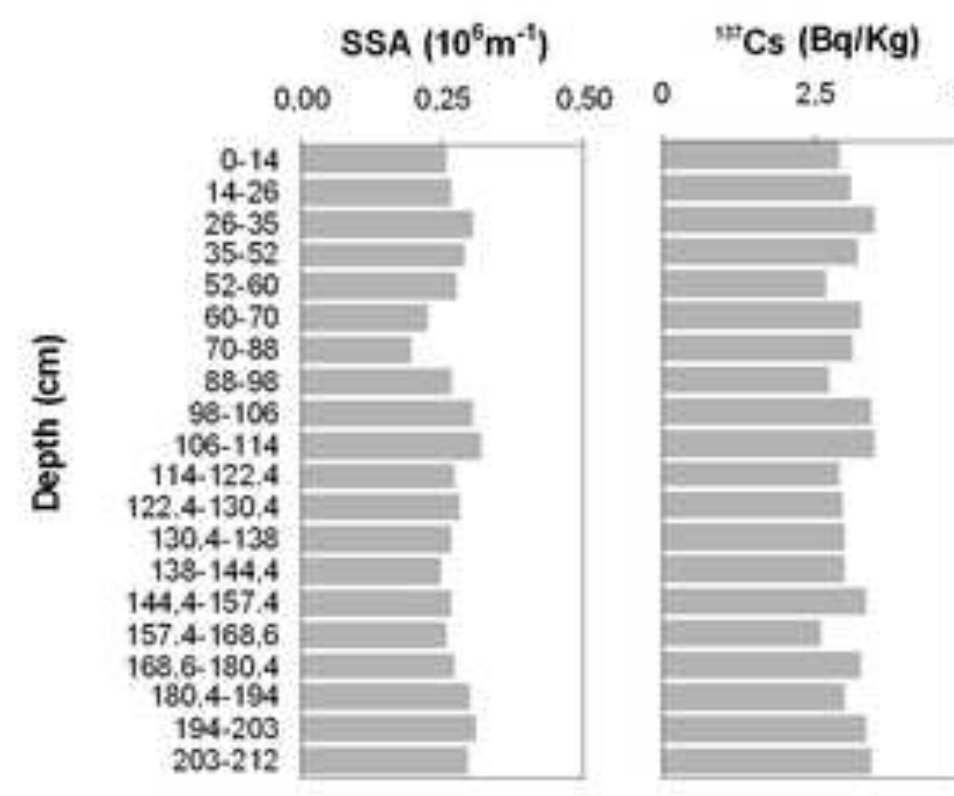

TOC $1 \%$

TN $(\%)$

$P_{-} \mathrm{P}_{2} \mathrm{O}_{5}(\%)$

50

0.75

1.50

0,1

0,20

0,1

0,2
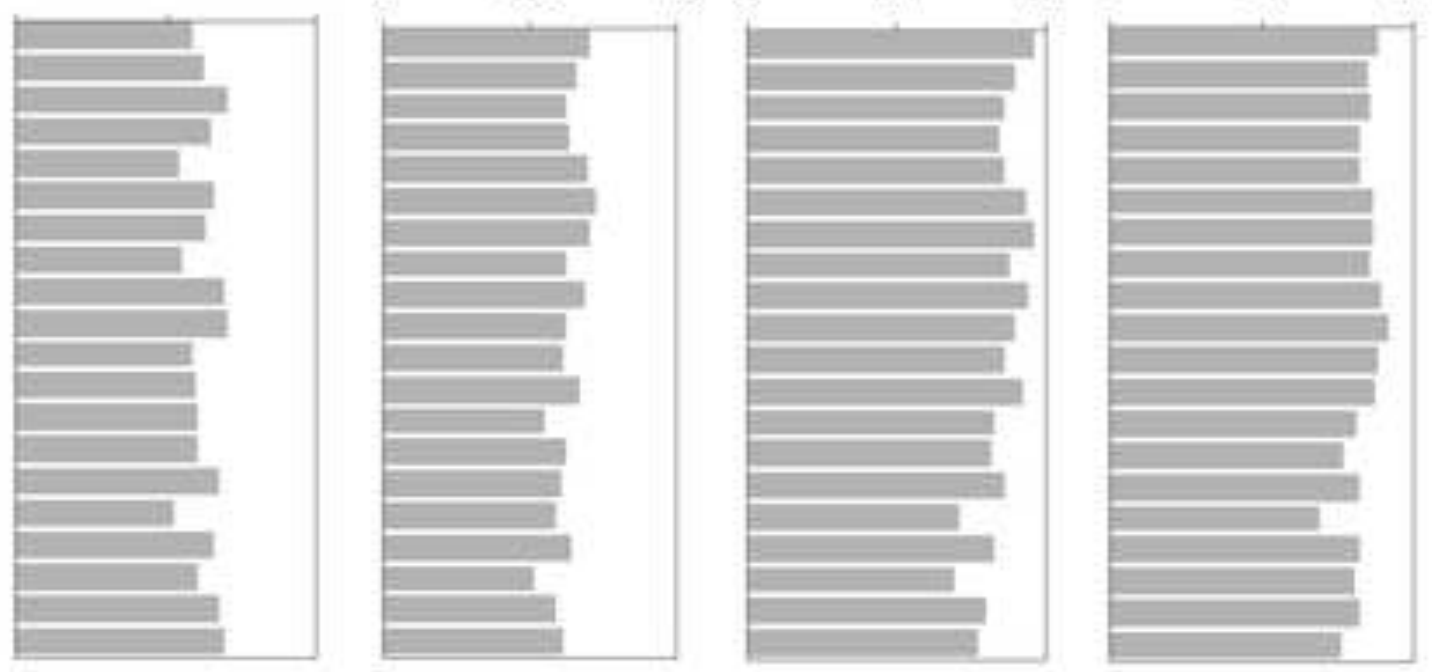

\section{CORE C9}
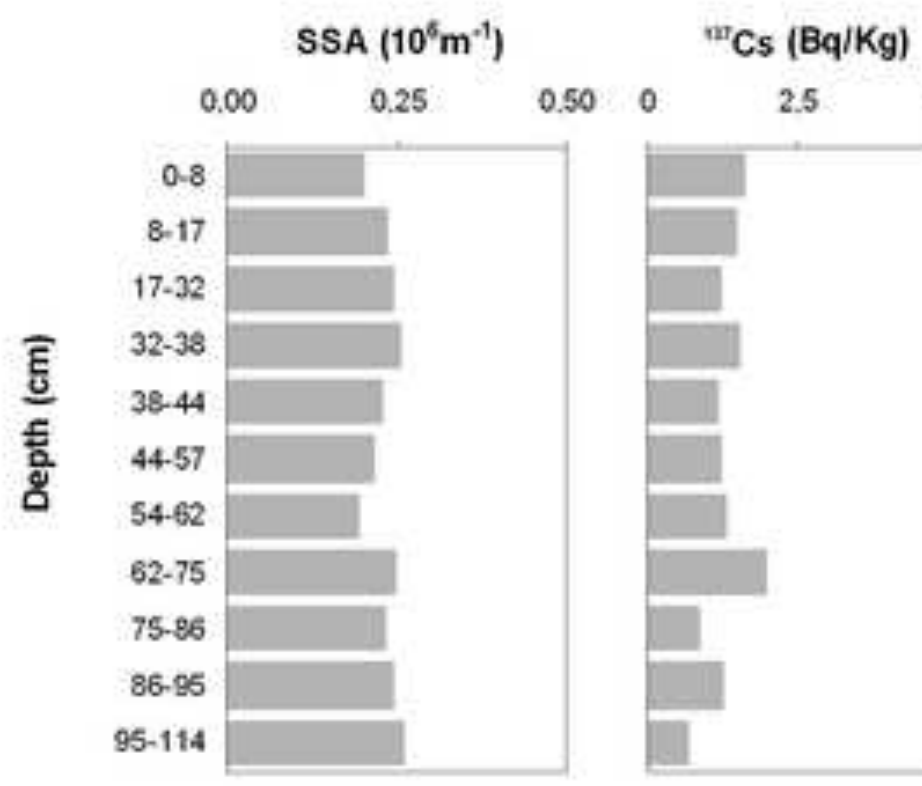

2.5
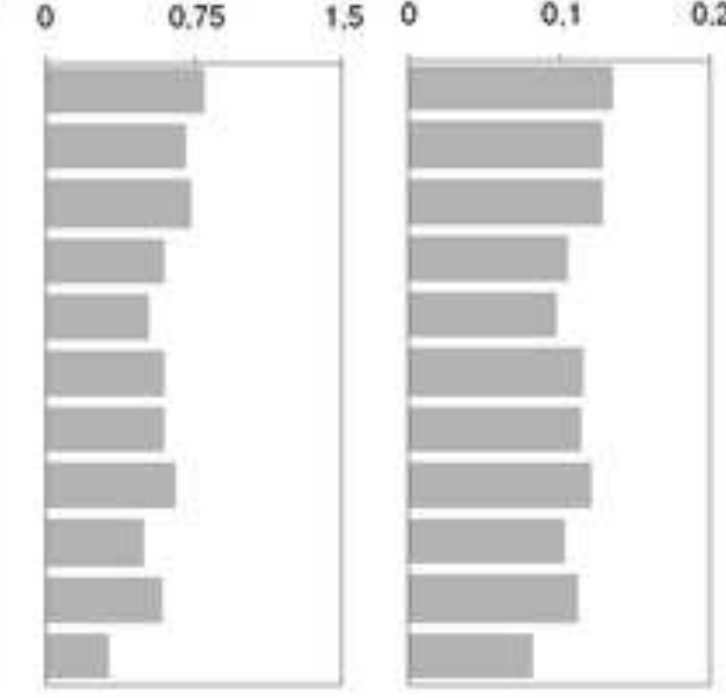

$0.20 \quad 0,1$

0,2
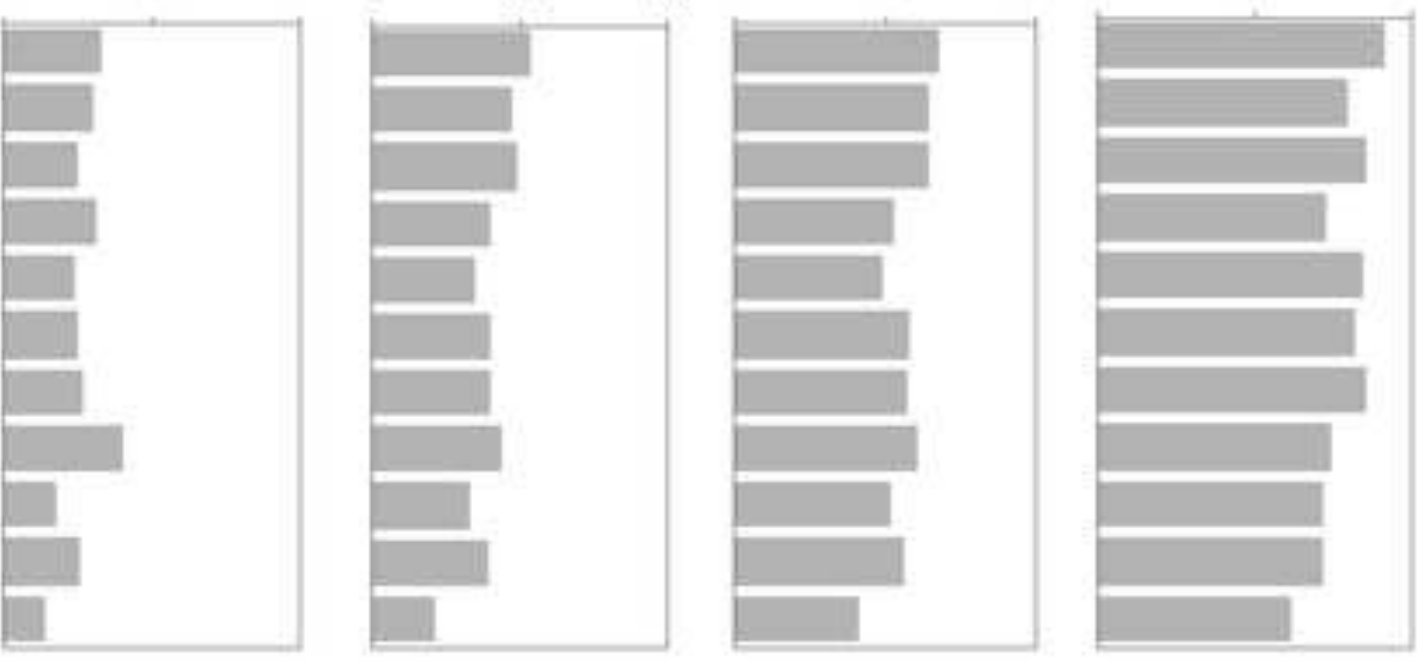


\section{Surface topsoil apportionment}

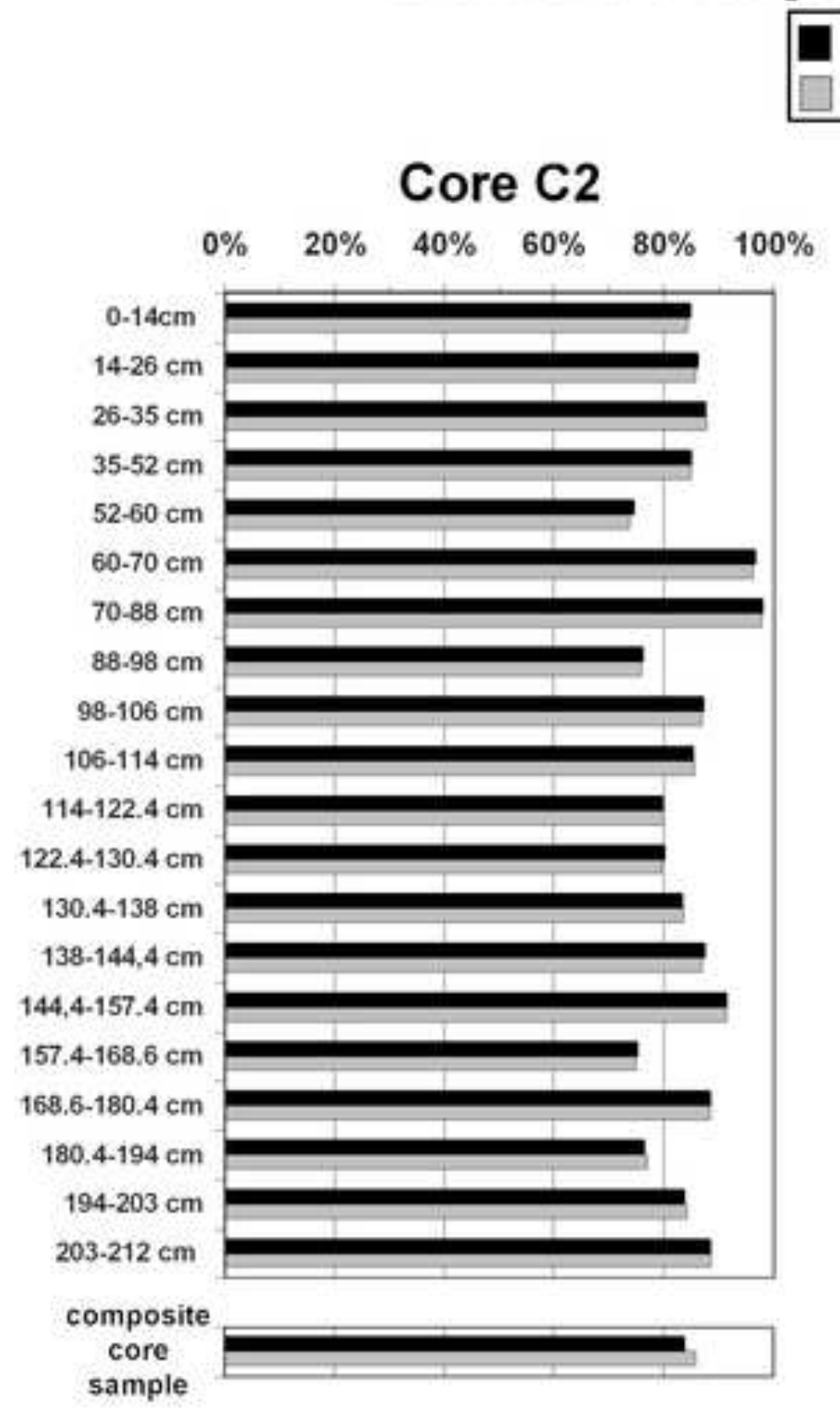

Core C9

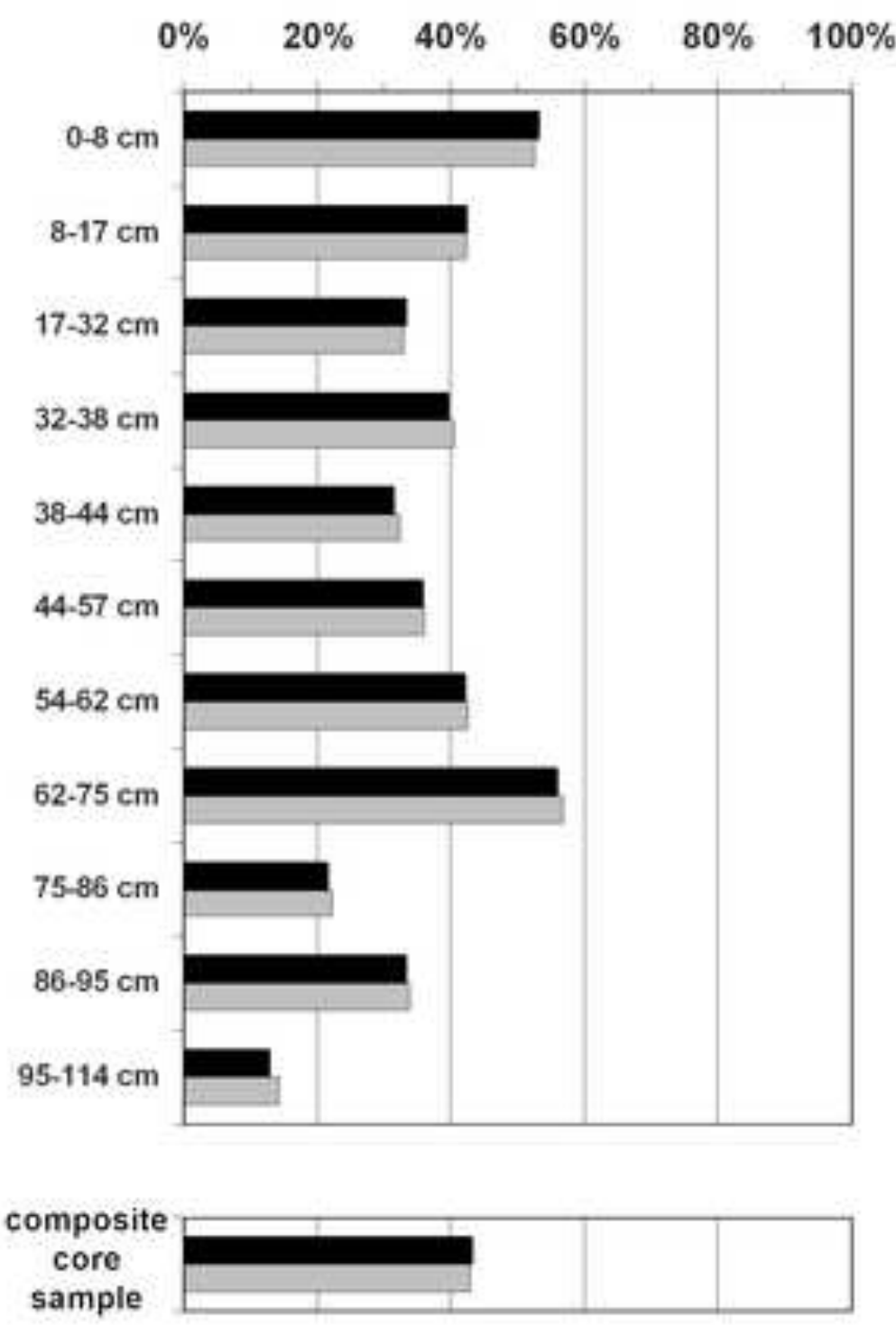




\section{Surface topsoil apportionment}

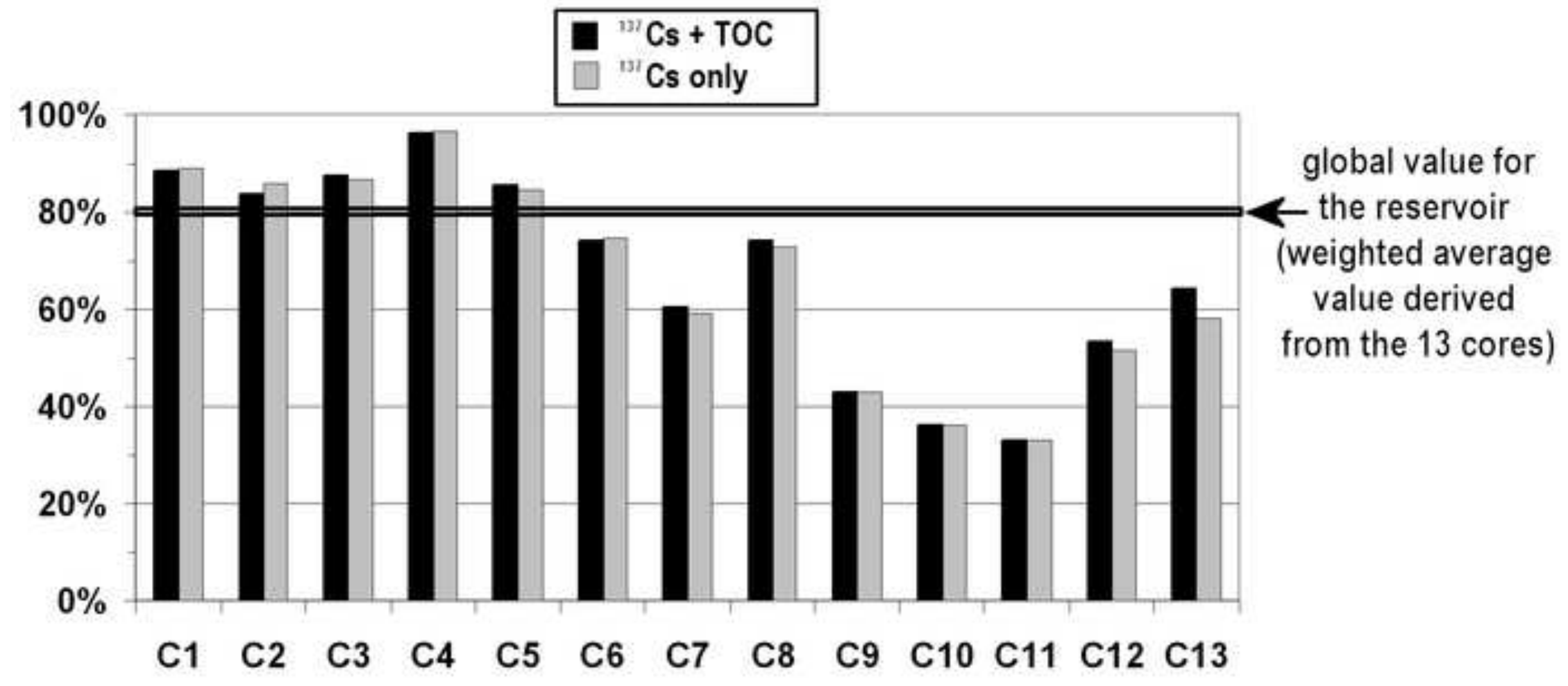




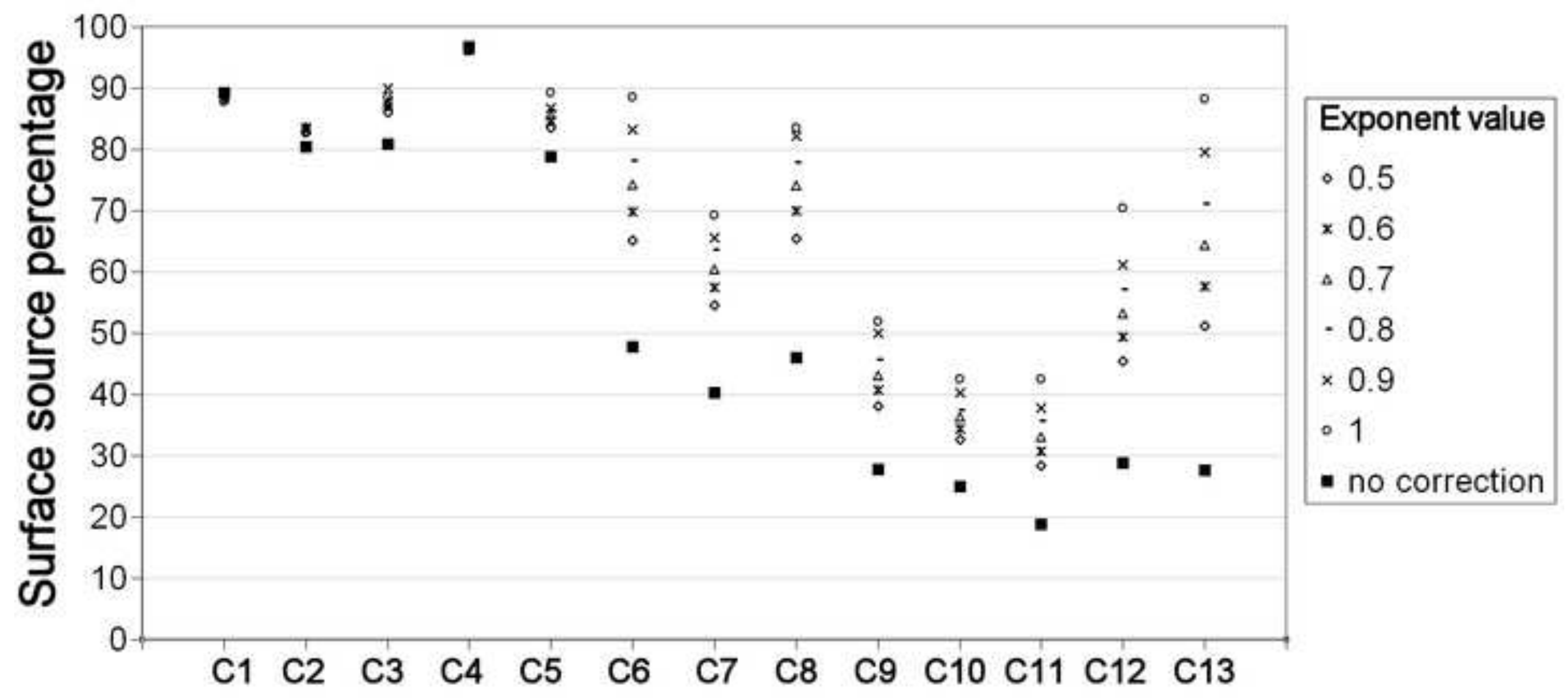




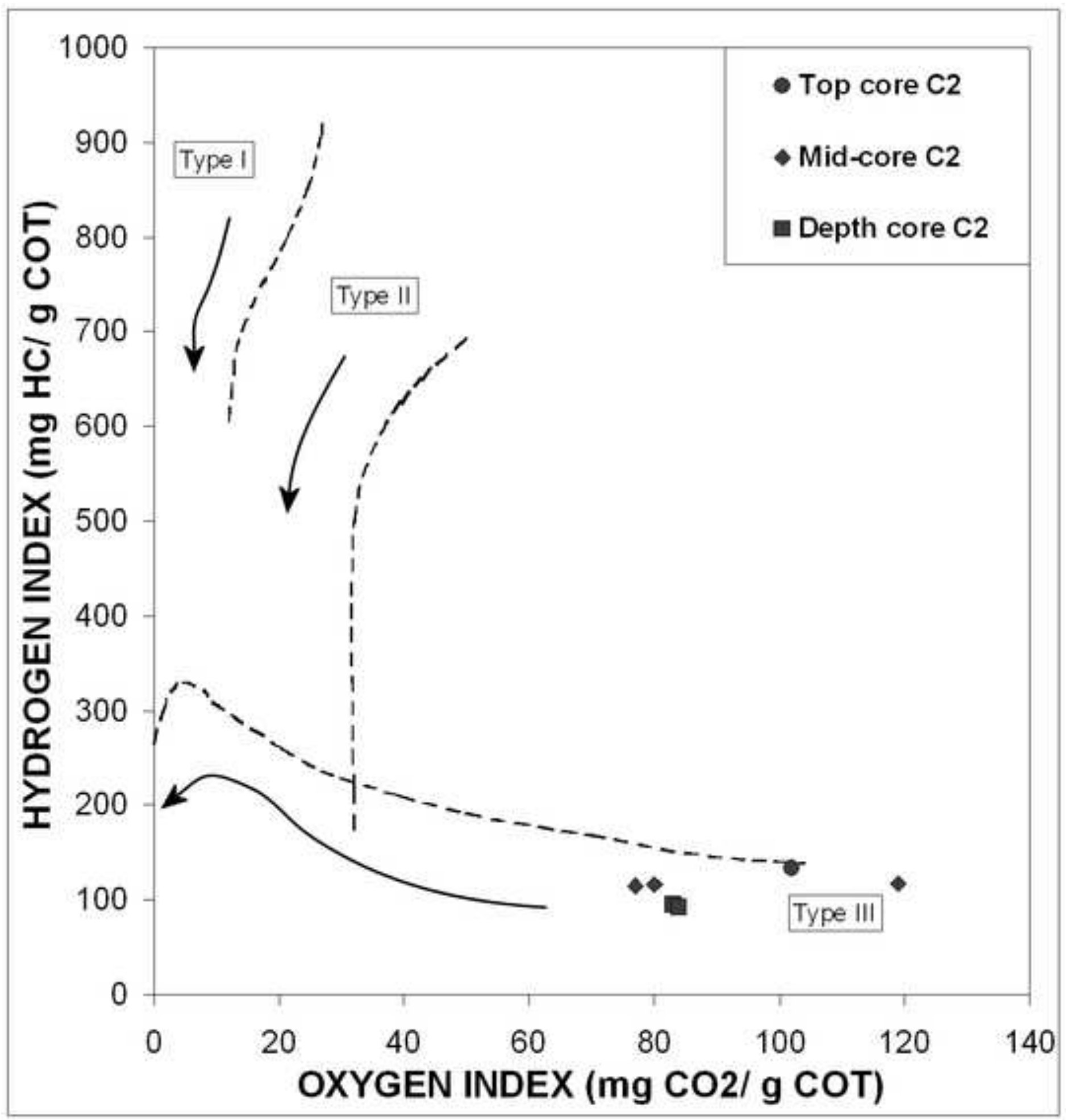

